Review

\title{
Biosynthesis Pathways, Transport Mechanisms and Biotechnological Applications of Fungal Siderophores
}

\author{
Lorenzo Pecoraro ${ }^{1, *++} \mathbb{D}$, Xiao Wang ${ }^{1,+} \mathbb{C}^{D}$, Dawood Shah ${ }^{1,2}$, Xiaoxuan Song ${ }^{1}$, Vishal Kumar ${ }^{3}$, Abdul Shakoor ${ }^{1,4}$, \\ Keshawanand Tripathi ${ }^{5}\left(\mathbb{D}\right.$, Pramod W. Ramteke ${ }^{6}$ and Rupa Rani ${ }^{1,7}$ (D)
}

1 School of Pharmaceutical Science and Technology, Tianjin University, 92 Weijin Road, Tianjin 300072, China; wang_xiao1996@163.com (X.W.); dawoodshah616@gmail.com (D.S.); harusong@163.com (X.S.); abdul_shakoor954@yahoo.com (A.S.); ruparani719@gmail.com (R.R.)

2 Institute of Biotechnology and Genetic Engineering, The University of Agriculture Peshawar, Peshawar 25000, Pakistan

3 Department of Food Science and Technology, Yeungnam University, Gyongsan 38541, Korea; vkaggarwal180@gmail.com

4 College of Geography and Environmental Science, Henan University, Kaifeng 475004, China

5 Center for Conservation and Utilization of Blue-Green Algae, ICAR-Indian Agricultural Research Institute, New Delhi 110012, India; tripathikn009@gmail.com

6 Faculty of Life Sciences, Mandsaur University, Mandsaur 458001, India; pwramteke@gmail.com

7 Department of Environmental Science and Engineering, Indian Institute of Technology (Indian School of Mines), Dhanbad 826004, India

* Correspondence: lorenzo.pecoraro@tju.edu.cn; Tel.: +86-185-2082-4550

+ Co-first author.

check for updates

Citation: Pecoraro, L.; Wang, X.;

Shah, D.; Song, X.; Kumar, V.; Shakoor, A.; Tripathi, K.; Ramteke, P.W.; Rani, R. Biosynthesis Pathways, Transport Mechanisms and Biotechnological Applications of Fungal Siderophores. J. Fungi 2022, 8 , 21. https://doi.org/10.3390/ jof8010021

Academic Editor: Baojun Xu

Received: 8 December 2021

Accepted: 21 December 2021

Published: 28 December 2021

Publisher's Note: MDPI stays neutral with regard to jurisdictional claims in published maps and institutional affiliations.

Copyright: (C) 2021 by the authors. Licensee MDPI, Basel, Switzerland. This article is an open access article distributed under the terms and conditions of the Creative Commons Attribution (CC BY) license (https:// creativecommons.org/licenses/by/ $4.0 /)$.
Abstract: Iron $(\mathrm{Fe})$ is the fourth most abundant element on earth and represents an essential nutrient for life. As a fundamental mineral element for cell growth and development, iron is available for uptake as ferric ions, which are usually oxidized into complex oxyhydroxide polymers, insoluble under aerobic conditions. In these conditions, the bioavailability of iron is dramatically reduced. As a result, microorganisms face problems of iron acquisition, especially under low concentrations of this element. However, some microbes have evolved mechanisms for obtaining ferric irons from the extracellular medium or environment by forming small molecules often regarded as siderophores. Siderophores are high affinity iron-binding molecules produced by a repertoire of proteins found in the cytoplasm of cyanobacteria, bacteria, fungi, and plants. Common groups of siderophores include hydroxamates, catecholates, carboxylates, and hydroximates. The hydroxamate siderophores are commonly synthesized by fungi. L-ornithine is a biosynthetic precursor of siderophores, which is synthesized from multimodular large enzyme complexes through non-ribosomal peptide synthetases (NRPSs), while siderophore-Fe chelators cell wall mannoproteins (FIT1, FIT2, and FIT3) help the retention of siderophores. S. cerevisiae, for example, can express these proteins in two genetically separate systems (reductive and nonreductive) in the plasma membrane. These proteins can convert $\mathrm{Fe}$ (III) into Fe (II) by a ferrous-specific metalloreductase enzyme complex and flavin reductases (FREs). However, regulation of the siderophore through Fur Box protein on the DNA promoter region and its activation or repression depend primarily on the Fe availability in the external medium. Siderophores are essential due to their wide range of applications in biotechnology, medicine, bioremediation of heavy metal polluted environments, biocontrol of plant pathogens, and plant growth enhancement.

Keywords: fungal cytoplasm proteins; iron uptake; iron-binding molecules; siderophore biosynthesis; hydroxamate; siderophore-Fe chelators mannoproteins; biotechnology; medicine; biocontrol; bioremediation

\section{Introduction}

Iron plays a vital role in the growth and development of living organisms, and it is one of the most abundant elements found on earth [1]. Mineral bioweathering is important 
in soil ecosystems because it increases the availability of iron for colonizing organisms, which is limited in oxygenic environments [2,3]. Indeed, Fe is converted into insoluble oxyhydroxide polymers under aerobic conditions at biological $\mathrm{pH}$ (oxidized form) [4]. Plants require $\left(10^{-5}-10^{-7} \mathrm{M}\right)$ of $\mathrm{Fe}$ (II) for growth and development, whereas the solubility of Fe (III) in nature is $10^{-17} \mathrm{M}$ at pH 7 [5]. During the evolution of life on earth, the majority of iron was in insoluble Fe (III) forms. Therefore, microorganisms including fungi, bacteria, and cyanobacteria adapted to low iron availability levels and overcame iron deficiency by synthesizing siderophores [6-8]. Siderophores are low molecular weight compounds (200-2000 Da) produced by different microbes, which chelate the iron from different habitats [9]. Scientific data have shown the ubiquitous presence of siderophores in plants and microbes. A significant number, i.e., 500 fungal and bacterial siderophores, are documented [10]. Furthermore, mammalian siderophores have also been reported [11]. Several laboratory methods, including spectrophotometric titration, electrophoretic mobility, mass spectrometry, acid hydrolysis, and biological activity tests are used to characterize siderophores [12].

Fe plays an essential role in vital functions, including photosynthesis, respiration, synthesis of DNA, RNA, proteins, and enzyme cofactors [13]. In human serum, transferrin is an iron transport protein that maintains Fe (III) concentration (10-24 M) and blocks the entry of pathogens [14]. Fungi and other microorganisms adopt various strategies for iron acquisition from the extracellular environment by (i) use of metal ion transporters [15], (ii) acquisition from heme and heme containing-proteins [16], (iii) acquisition from transferrin, lactoferrin, and ferritin $[17,18]$, (iv) use of reductive systems of iron uptake, and (v) siderophore-mediated iron transport [8]. Siderophore-mediated Fe-scavenging is an essential process in soil ecosystems that improves the bioavailability of iron derived from mineral dissolution via bioweathering. Siderophores primarily scavenge iron through complex formation with other metals such as molybdenum and cobalt [19]. These compounds promote plant growth and play an important role in pathogen biocontrol [20] and bioremediation of metal-polluted environments [21].

Fungal siderophores are very diverse and show striking structures. Fungi usually produce hydroxamate and carboxylate siderophore types, which have been primarily studied in Aspergillus species. For instance, A. fumigatus and A. nidulans synthesize about 55 types of siderophores. Both species live as saprotrophs, contributing to maintaining carbon and nitrogen cycles in the environment [8]. Many fungi can produce more than one siderophore type, especially under low iron availability. Aspergillus fumigatus often produces a hydroxamate siderophore and triacetyl fusarine C (TAFC) for tapping extracellular iron [22]. This fungus can also secret a siderophore called ferricrocin for mobilization and distribution of hyphal iron, and intracellular iron storage. Besides, A. fumigatus synthesizes the conidial siderophore 'hydroxyferricrocin' for storing iron in its conidia to support the germination process and reduce oxidative stress [23]. Aspergillus nidulans has been reported to produce two main siderophores, ferricrocin (Frr) and ferrihordin. A twenty-four hour culture of A. nidulans produced an unacetylated form of TAFC, which is known as fusigen. In contrast, an older strain ( $48 \mathrm{~h}$ ) yielded acetylated TAFC due to breakdown and uptake of fusigen [24] Another fungus, Wolfiporia cocos, known as a brown-rot fungus, may produce different types of catecholate siderophores [25]. According to Haselwandter et al. [26], the two ubiquitous ectomycorrhizal basidiomycetes Laccaria laccata and L. bicolor can produce linear ester-containing Fsg siderophores, i.e., CPG, Frr and TAFC, apart from the hydroxamates.

Many researchers are now interested in knowing how some fungal strains have evolved to produce different types of siderophores, what are the suitable conditions for the production of siderophores, how siderophores, in general, can contribute to fungal survival, and what are the structural differences between fungal siderophores. Indeed, many studies have used structural and stereochemical analyses to describe the properties of fungal siderophores, while attempts have been made to understand the production, recognition, and transportation mechanism of siderophores in different fungal species. Some members of siderophore classes have been characterized by crystalline structures, the 
absolute metal center configuration, and conformation in solutions [8,27]. Understanding of chemical and structural properties and transport mechanisms of fungal siderophores has also inspired many researchers. Ferrichromes (FRC), for example, are the best studied siderophores and are now regarded as biomolecules. However, there is still a dearth of knowledge on how siderophores are designed for transport. Except in plants, nothing is known about the possible membrane-located transport system for siderophores in the fungal plasma membrane.

Further studies are still needed to describe in detail, or confirm, the protein nature of many fungal siderophores. However, some studies have already clarified the energy requirement for siderophore-mediated iron transport in fungi. There is evidence suggesting that the transportation of siderophores can be mechanically transferred across the cytoplasmic membrane. However, it is still not fully known yet to what extent this is possible.

\section{Overview of Fungal Siderophores}

Fungi are heterotrophic eukaryotic organisms [28]. Among them, saprobic fungal species are decomposers that break down and feed on decaying organic matter. Many fungi show two major responses to iron concentration in the environment: siderophore synthesis under iron stress, and a high-affinity ferric iron reductase [29]. On the basis of chemical interaction sites, siderophores have been classified into two major groups, i.e., Enterobactin and Hydroxamates. Enterobactin is regarded as a good iron chelator, which has the ability to interact with iron and catecholate hydroxyl groups. Hydroxamates are unique, due to the presence of $\mathrm{N}$-hydroxylated amide bonds. The hydroxamate siderophores, such as FRC, are commonly produced by fungi. Siderophores that are synthesized by microbes and plants are classified based on coordinating groups and Fe binding system, including (i) phenolates, (ii) hydroxamates, (iii) polycarboxylates (Table 1). Common types of siderophores are hydroxamates, catecholates, and carboxylates [30]. Nitrogen, oxygen, and sulfur atoms can take part in iron coordination in the carboxylate group of siderophores [31,32]. Another group of siderophores is known as the mixed type. Mixed type siderophores do not belong to hydroxamate and the aromatic hydroxyl category. These hybrid types of siderophores are classified based on the position of the Fe (III) binding group. Mixed-type siderophores can bind salicylic acid and nitrogen [4]. Common examples of mixed type siderophores are (i) lysine derivatives, such as myobactin, (ii) ornithine derivatives, including pyoverdine, and (iii) histamine derivatives, such as anguibactin. Other examples are thiazoline, oxazoline, and pyoverdine. Pyoverdine, in particular, has been reported as a signaling molecule in the bacterium Pseudomonas aeruginosa [33] and as an inhibitor molecule against zinc-containing matrix metalloproteinases (MMPs), which often degrade in extracellular matrixes [34]. The main groups of siderophores are itemized in Figure 1. Many phytopathogenic fungi synthesize unique compounds to chelate iron, but also produce phytotoxins. Fungi mainly synthesize hydroxamate-type siderophores (derived from the nonproteinogenic ornithine amino acid) (Table 1). 
Table 1. Types of siderophores and their characteristics.

\begin{tabular}{|c|c|c|c|}
\hline Siderophores & Types & Characteristics & References \\
\hline \multirow[t]{2}{*}{ Hydroxamates } & Rhodotorulic acid & $\begin{array}{l}\text { The diketopiperazine ring of } \\
\text { N5-acetyl-N5-hydroxy-L-ornithine units linked } \\
\text { head-to-head. Produced mainly by basidiomycetous } \\
\text { yeasts such as Rhodotorula spp. }\end{array}$ & Haas [35]; Das et al. [36] \\
\hline & Coprogens & $\begin{array}{l}\text { The diketopiperazine ring (dimerum acid) of } \\
\text { diketopiperazine ring (dimerum acid) units linked } \\
\text { head-to-head. Produced generally by a number of plant } \\
\text { pathogens, such as H. capsulatum, B. dermatitidis, } \\
\text { Fusarium dimerum and Curvularia lunata. These are di or } \\
\text { tri-hydroxamates derivatives of rhodotorulic acid with a } \\
\text { linear structure composed of trans-fusarinine units. }\end{array}$ & Haas [35]; Das et al. [36] \\
\hline
\end{tabular}

Cyclic hexapeptides consisting of tripeptide of

$N$-acyl- $N$-hydroxyornithine and three amino acids, serine, glycine and alanine. Several different acyl groups have been found in this family such as acetyl, malonyl,

Ferrichromes transb-ethylglutaconyl, trans-anhydromevalonyl, and cis-anhydromevalonyl. Ferrichromes are produced by phytopathogenic fungi and by Microsporum sp., Trichophyton sp., and Aspergillus spp. Another function of ferrichromes is the intracellular storage of iron.

Linear or cyclic hydroxamates composed of

Fusarinines N-hydroxyornithine, which is N-acylated by anhydromevalonic acid. Produced by Fusarium spp.,

Das et al. [36] Paecilomyces spp., and Aspergillus spp.

A citric acid-containing polycarboxylate called rhizoferrin has been isolated from Rhizopus microsporus var. rhizopodiformis. The molecule is composed of two

Polycarboxylates Rhizoferrin citric acid units linked to diaminobutane. Produced mainly by Mucoromycota, Mucorales (Mucoraceae, Thamnididiaceae, and Choanephoraceae) and Mortierellales (Mortierellaceae), and Entomophthoromycota, Entomophthorales.

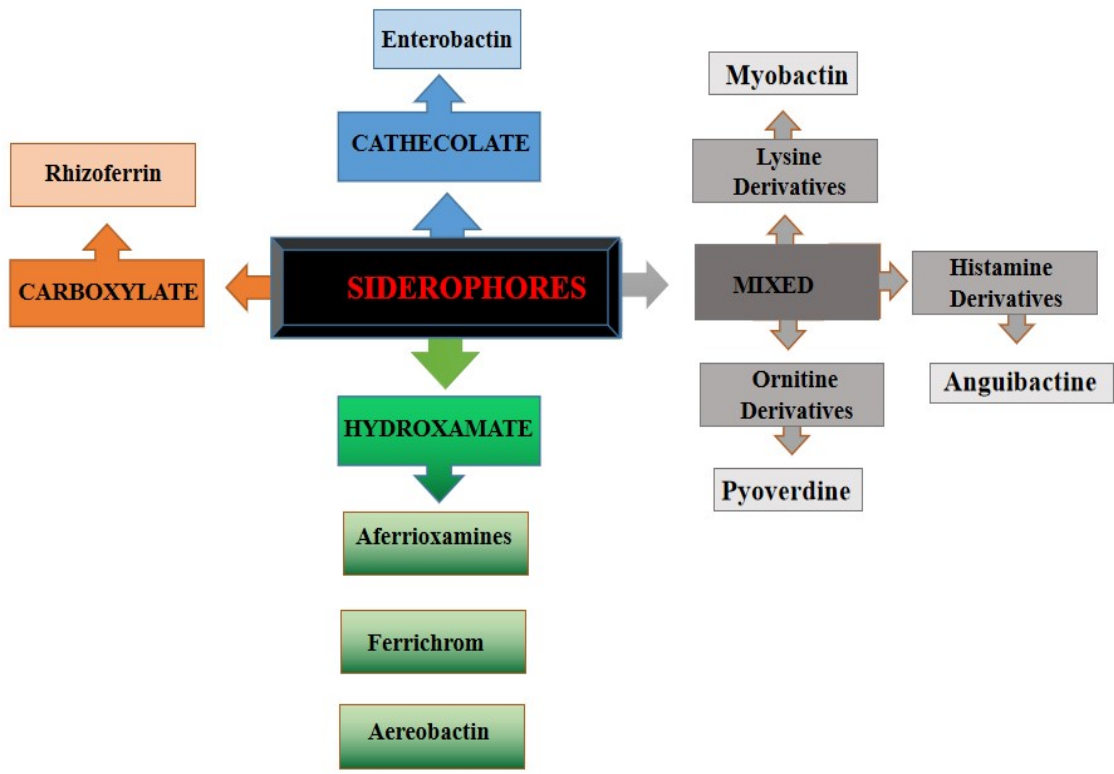

Figure 1. General groups of siderophores. 
Hydroxamates are further categorized into three groups: (i) fusarinines (FSR), (ii) coprogens (CPG), (iii) FRC, with a few exceptions, such as the rhizoferrin (Figure 2). Rhizoferrin is a carboxylate-type siderophore produced by certain zygomycetes. Siderophore synthesis by fungi depends on the nutrient medium and culture conditions. Hydrophilic siderophores are derived from the common structural unit $\mathrm{N}^{\delta}$-hydroxyornithine. In fungi, they consist of hydroxylated and alkylated ornithine amino acid, while in bacteria, they are acylated and hydroxylated alkylamines [37], represented by $\mathrm{N}^{6}$-acyl- $\mathrm{N}^{6}$ Hydroxylysine or $\mathrm{N}^{5}$-acyl- $\mathrm{N}^{5}$-Hydroxyornithine reported by Winkelmann [38]. All hydroxamate siderophores are characterized by peptide linkage [24], except fusarinine C (FsC), synthesized by Aspergillus nidulans, which shows ester bonds. Two $\mathrm{O}_{2}$ molecules of these groups bind with $\mathrm{Fe}$, known as bi-dentate ligand. Hydroxamate siderophores are capable of binding hexadentate octahedral complex with Fe (III) [39].

Fungi synthesize more than one type of siderophore belonging to a single structural family or different structural families. For instance, Trichoderma pseudokoningii and T. longibrachiatum synthesize all three structural families of siderophores [40]. The FSR (fusarinine) is a siderophore synthesized by young cultures of Fusarium roseum, whereas at the older stage of culture, FSR is replaced by malonichrome. Siderophore identity is a valuable trait in fungal taxonomy [41]. In fact, wide ranges of siderophores are found within a fungal genus. Mor et al. [42] found that siderophore production in Trichophyton and Microsporum species are similar. For instance, T. rubrum and T. mentagrophytes produced siderophores that are also synthesized by Microsporum taxa. The same siderophores, ferrichrome $C$ and ferricrocin, are produced in Microsporum species, including M. canis and M. gypseum. In contrast, $T$. mentagrophytes and T. Tonsurans produce only ferrichrome. Other fungal siderophores are described in Table 2.<smiles>CC(=O)N(O)CCCC1NC(=O)C(CCCN(O)C(C)=O)NC1=O</smiles>

Rhodotorulic acid

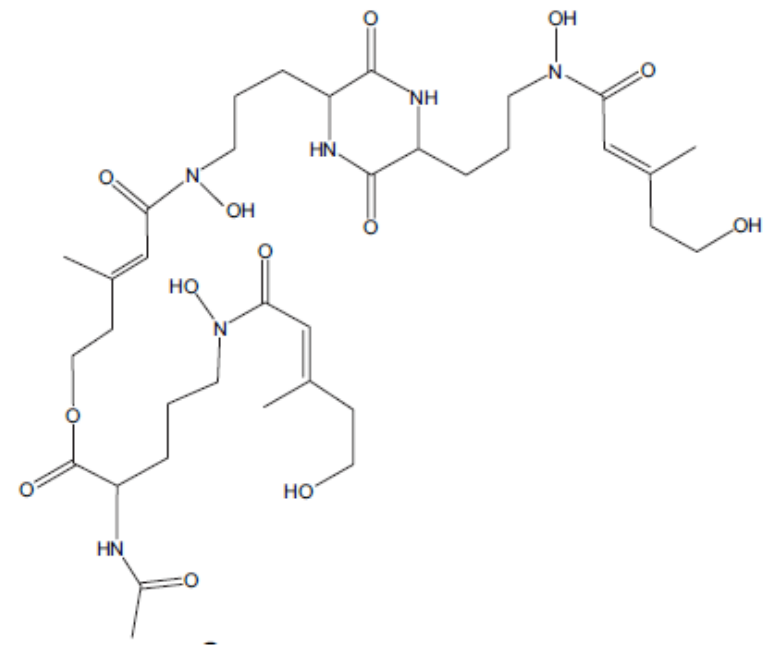

Coprogens

Figure 2. Cont. 


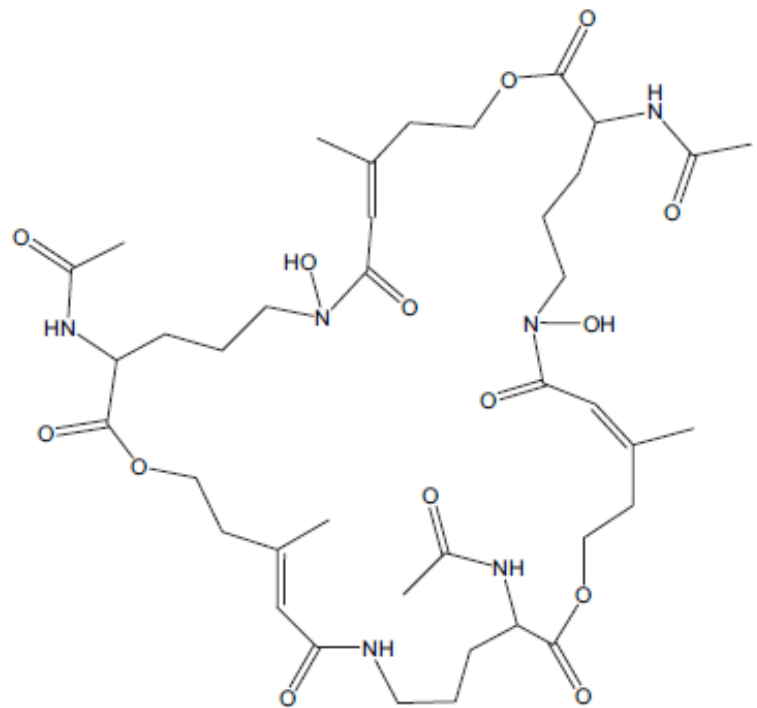

Triacetylfusarinine C<smiles>CC(=O)NC(=O)C(CCCN(O)C(C)=O)NC(=O)C(CCCN(O)C(C)=O)NC(=O)CNC(=O)C(CO)NC(=O)CNC(=O)C(CCCN(O)C(C)=O)NC(=O)CNC(=O)C(O)CCCN(O)C(C)=O</smiles>

Ferricrocin

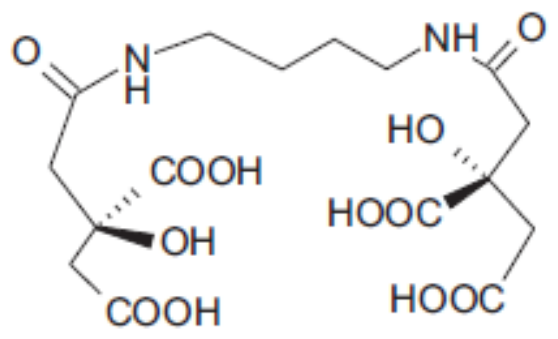

Rhizoferrin

Figure 2. Structure of fungal siderophores.

Table 2. Some examples of fungal siderophores.

\begin{tabular}{ccc}
\hline Fungal Source & Siderophores & References \\
\hline $\begin{array}{c}\text { Aspergillus sp., Penicillium oxalicum, } \\
\text { Aureobasidium pullulans, Phanerochaete } \\
\text { chrysosporium }\end{array}$ & Hydroxamates & Ghosh et al. [22] \\
\hline Alternaria longipes & $\begin{array}{c}\text { Trihydroxamate (Hydroxycoprogen I, } \\
\text { Hydroxyneocoprogen I) }\end{array}$ & Jalal and Helm [43] \\
\hline A. longipes & $\begin{array}{c}\text { Trihydroxamate ( }{ }^{\mathrm{b}} \text {-dimethyl coprogen, } \\
\mathrm{N}^{\mathrm{b}} \text {-dimethyl neocoprogen I and } \\
\mathrm{N}^{\mathrm{b}} \text {-dimethyl isoneocoprogen }\end{array}$ & Jalal et al. [44] \\
\hline Candida sp. & Ferrichrome, hydroxamates & Baakza et al. [37] \\
\hline Curvularia lunata & Trihydroxamate (Neocoprogen II) & Hossain et al. [45] \\
\hline Epicoccum purpurascens (Syn. E. & Trihydroxamate (Isoneocoprogen I or \\
nigrum $)$ & Triornicin) & Frederick et al. [46] \\
\hline E. nigrum and C. lunata & Trihydroxamate (Isotriornicin or \\
Fusarium dimerum & Neocoprogen I) & Frederick et al. [46]; Chowdappa et al. [47] \\
\hline F. roseum & Dihydroxamate (Dimerum acid) & Diekmann [48] \\
\hline dimerum & Cis-fusarinine & Emery [49]
\end{tabular}


Table 2. Cont.

\begin{tabular}{ccc}
\hline Fungal Source & Siderophores & References \\
\hline F. dimerum & Trihydroxamate (Coprogen B) & Diekmann [48] \\
\hline Gliocladium virens & Fusarinine A, Fusarinine B & Jalal et al. [50] \\
\hline Neurospora crassa & Neurosporin & Eng-Wilmot et al. [51] \\
\hline Penicillium sp. & Trihydroxamate (Coprogen) & Pidacks et al. [52] \\
\hline Penicillium sp. & N, N'N'-triacetylfusarinine C & Moore and Emery [53] \\
\hline Paracoccidioides sp. & Hydroxamates & Lesuisse et al. [54] \\
\hline Rhizopus microsporus & Carboxylates (rhizoferrin) & Drechsel et al. [31] \\
\hline Rhodothamus chamaecistus & Fusarinine C (FsC), Fusigen & Haselwandter et al. [55] \\
\hline Saccharomyces cerevisiae & Catecholate, hydroxamate, ferrioxamine, & Senthilnithy [56] \\
\hline Trichoderma sp. & ferricrocin & Anke et al. [40] \\
\hline Trichoderma sp. & Hydroxamates, carboxylates & Baila et al. [57]
\end{tabular}

\section{Biosynthesis of Siderophores and Regulation}

Biosynthesis of siderophores is divided into two major pathways: nonribosomal peptide synthetase (NRPS)-dependent, and NRPS-independent [60,61]. NRPSs are large multimodular enzyme complexes. They consist of adenylation domain (A), thiolation domain (T), condensation domain (C), and thioesterase domain (TE). Each module of the NRPS enzymes is responsible for adding amino acids (AAs) and forming peptide bonds. NRPS enzymes determine the sequence and number of AAs in the peptide chain [62]. NRPS recognizes and activates AAs by activating A-domain and acylating adenylate via an ATP-dependent reaction. The next steps are thiolation of (T) domain, in which the activated ester is covalently linked, followed by condensation of the (C) domain, and direct transfer of another acyl amino acid to form a peptide bond [63]. The thioesterase domain (TE) is present in the final unit. The last step consists of assembling or releasing chains from the NRPS by hydrolysis or cyclization. Cleavage of the acyl thioester, which binds to the T domain, is an NADH-dependent reaction [64]. Fungi commonly use four main mechanisms for iron uptake across the cytoplasmic membrane as follows: (i) A shuttle mechanism in which the siderophore bound iron can be taken into the cell and the iron is released by a reductase or by direct ligand exchange in which the recipient siderophore becomes the storage molecule. The gathering ligand is released to capture another iron molecule. This type of transfer has been used by coprogen and ferrichrome families. (ii) A direct transfer mechanism in which iron is taken up (iron is first reduced by the reductive pathway before taken up) while the ligand remains outside the cell. The iron transfer is not a membrane-reductive event but is a membrane-mediated exchange between the gathering siderophore and an internal chelating agent. The transfer mechanism may be by ligand exchange (nonenzymatic) to an internal pool of the chelating agent, which then serves as the storage compound. This type of transfer has been used by rhodotorulic acid. (iii) An esterase-reductase mechanism in which iron ligand is taken up and ester bonds of the iron ligand are split to excrete fusarinine moieties, followed by reduction and storage of ferric iron. This type of transfer has been used by ferric triacetylfusarinine C. (iv) A reductive mechanism with the transport of some ferrichromes, which do not to enter cells but give up ferric iron by reduction with transport of the ferrous iron [36].

Hydroxamate fungal siderophores have similar biosynthetic pathways in terms of their basic unit, characterized by hydroxyornithine $[65,66]$. Figure 3 represents a general schematic biosynthetic pathway [67]. The first step is the hydroxylation of L-ornithine. This is a precursor of siderophores, which is converted into $N$-hydroxy-L-ornithine in a reaction 
catalyzed by the enzymes L-ornithine and L-ornithine $\mathrm{N}^{5}$-oxygenase $[61,68]$. The second step is the acylation of N-hydroxy L-ornithine to form $\mathrm{N}$-acyl- $\mathrm{N}$-hydroxy-L-ornithine in the presence of the enzyme transacetylase [67]. The acyl-CoA derivative is an acyl donor, and the reaction is catalyzed by acyl-CoA: N-hydroxy-L-ornithine $\mathrm{N}$-acyl transferase. This step has been reported in Ustilago sphaerogena $[69,70]$, while $\mathrm{N}$-acetyltransferase activity in siderophore biosynthetic pathways has been reported in Rhodotorula pilimanae [71]. $\mathrm{N}$-acetyltransferase has also been reported in other fungi such as Fusarium cubense [72], Rhodotorula glutinis [73], and Aspergillus quadricinctus [67]. The following steps are the condensation of several N-acyl-N-hydroxy-L-ornithines combined in two to three units and the formation of dipeptides and triesters such as $\mathrm{FsC}$, rhodotorulic acid, and coprogen B [67]. Condensation of amino acid and formation of cyclic peptide FRC were reported in Aspergillus quadricinctus [74]. Peptide biosynthesis in siderophore production and respective genes (sid2) have been described in Ustilago maydis and Trichoderma virens (Psy1) $[75,76]$. Disruption of these genes makes $U$. maydis and T. virens unable to synthesize ferrichrome $[76,77]$.

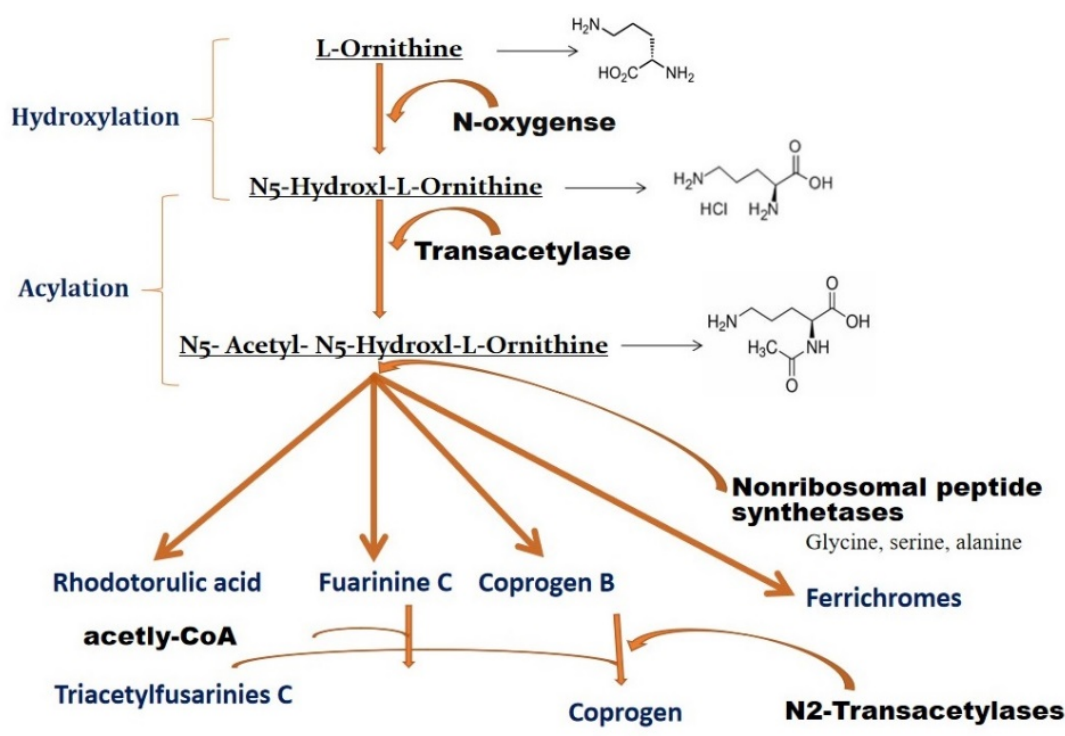

Figure 3. L-ornithine is the biosynthetic precursor of siderophores in fungi. Intermediate steps including hydroxylation, acylation and acetylation lead to the synthesis of Rhodotorulic acid, Fusarinine C and Coprogen (modified and adapted from Philpott [29]).

Transport of iron via siderophores is an investment of biosynthetic energy. The function of siderophores is mainly iron sequestration from an external medium. During excretion, siderophores are released, and a few of them are loaded with iron molecules for supporting the growth of the producing microorganism [78]. Therefore, the excretion of siderophores responds to the availability of iron in the external medium [79]. Fur is a ferric uptake regulatory protein produced in Gram-negative and positive bacteria [80]. A constitutive siderophore mutant in Salmonella was observed by Ernst et al. [80], and cloned [81]. The $\mathrm{Fur}^{+}$gene is repressed along with a number of genes involved in iron uptake [82]. The proposed repression model requires the Fur-protein's internal binding of ferrous iron and then binds to the Fur Box present on the target DNA. Inhibition of RNA polymerase is responsible for the search of the promoter region of the iron-regulatory region. Under limited iron conditions, transport systems and siderophore biosynthesis are activated, and Fur protein is separated from the Fur box on the DNA [83]. In fungi, transcriptional repressor (Fur) proteins are known as GATA factor proteins [84,85]. These proteins contain GATA-type zinc fingers that bind to the siderophore biosynthesis genes [86,87] (Figure 4). Table 3 represents negative fungal regulatory proteins in the biosynthesis and transport of siderophores. 


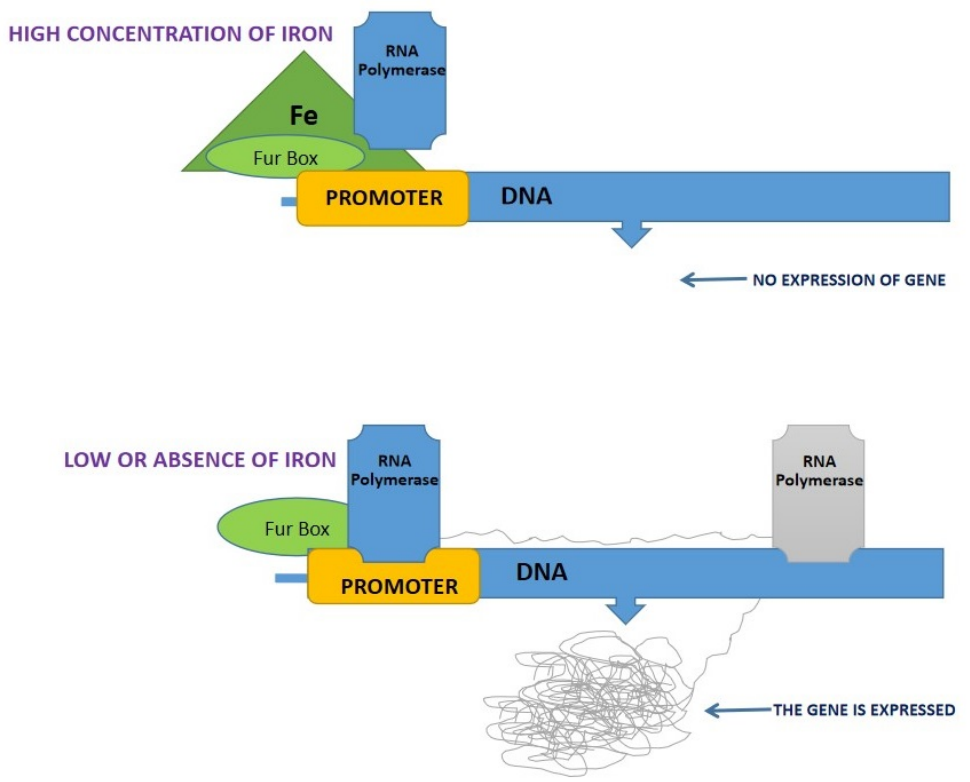

Figure 4. Regulatory model of biosynthesis of siderophore and Fur Box activation or repression: At the high iron concentration, formation of Fur box protein and iron complex in the promoter region of the DNA and RNA polymerases are unable to move forward due to the regression of the gene, while at low concentration of iron, Fur proteins release RNA polymerases leading to the expression of genes.

Table 3. Negative fungal regulatory proteins in the biosynthesis and transport of siderophores.

\begin{tabular}{cccc}
\hline S.No & Regulatory Protein Similar to GATA Factor & Organisms & References \\
\hline 1. & URBS1 & Ustilago maydis & Voisard et al. [88]; An et al. [86] \\
2. & SRE & Neurospora crassa & Zhou et al. [89] \\
3. & SREP & Penicillium chrysogenum & Haas et al. [90] \\
4. & SREA & Aspergillus nidulans & Haas et al. [91]; Oberegger et al. [24] \\
5. & GAF2p & Schizosaccharomyces pombe & Hoe et al. [92]; Pelletier et al. [93] \\
\hline
\end{tabular}

In iron-deficient conditions, C. albicans and S. cerevisiae use the Aft 1 transcription factor to bind with the promoter region of siderophore biosynthetic genes and activate the expression of genes [94,95]. Therefore, external ion concentration is the regulatory factor for intracellular biosynthesis of siderophores and transport proteins in microorganisms. The regulation of siderophore production and transporter proteins are the most important ecological aspects of siderophores. Iron sensing is a crucial step for the survival of competing microorganisms in natural environments. Iron sensing assists the microbes in adapting to ever-changing iron metabolism in different habitats [96]. Therefore, those microorganisms highly sensitive to iron regulation are more resistant to environmental changes. Previous research has provided insight into the low concentrations of iron in environments. Usually, iron-deficient environments are colonized by aerobic microorganism through up-regulation of siderophore biosynthetic genes and transport proteins [97]. The important question here is: where is the low iron content in natural habitats? The marine region, especially in the open oceans, calcareous soils, and freshwater lakes contain iron concentration in surface water in the nano-molar 0,2 to $1 \mathrm{nM}$ range [98] and inhibits growth of plankton, bacteria, and plants.

In the human body, free iron is absent, and if any iron is present, it is in protein-bound forms such as transferrin or lactoferrin and ferritin [99]. Pathogens can multiply in low iron environments by sequestering iron from host proteins using ferric-binding protein and transferrin-binding protein, as found in Neisseria. These transport proteins move from the periplasm to the cytosol [100]. Pseudomonas aeruginosa cell lysis and degradation of 
proteins by the proteases and subsequent iron scavenging by the excretion of siderophores is another method of iron acquisition. There are different routes by which pathogens can utilize iron from the host cells, but the most suitable system is siderophore mediated transport [101]. Another essential aspect of siderophore ecology is the energy saving. The siderophore biosynthesis requires energy, which is obtained from ATP and carbon sources. Siderophore production starts after the germination of conidiospores in fungi [102]. The conidiospores contain a certain amount of siderophores packed into the wall of the spore and secreted at the time of germination [103]. Siderophore genes are responsible for the sporulation in some fungal strains. Knock out of siderophore genes in fungi was shown to inhibit the sporulation process [104]. A notable example is the Aspergillus fumigatus conidial siderophore 'hydroxyferricrocin', which also aids in germination and oxidative stress tolerance [23].

\section{Siderophore Mediated Iron Transport in Fungi}

The fungal cell wall is made up of glucans, chitin, chitosan and glycosylated proteins, and shows a highly dynamic structure [105]. The outer layers of the fungal cell wall are composed of mannoproteins [106]. Mannoproteins affect cell permeability and are influenced by growth conditions. Indeed, mannoproteins allow the passage of nutrients across the cell wall to the periplasmic space and plasma membrane [54]. Regulation and uptake of iron molecules are essential in fungi for maintaining homeostatic processes. As a result, fungi commonly use four main mechanisms for iron uptake, including ferric iron $\left(\mathrm{Fe}^{3+}\right)$ uptake through the production of siderophores, iron assimilation through a redox reaction, heme uptake, and direct iron uptake [8,35]. Every fungal species exhibits an extracellular iron-uptake mechanism known as siderophore-iron transporter (SIT). This SIT, in principle, is constituted by a major protein family that facilitates iron uptake in fungi, acting through the help of the plasma membrane, with high solubility and energy, as a proton-coupled symporter, and releasing iron-chelated siderophore during cell growth. The triacetyl fusarine $\mathrm{C}$ (TAFC) and fusarinine $\mathrm{C}(\mathrm{FsC})$ have been found to enhance the iron release through partial hydrolysis by the esterase (Estb) enzyme [15].

The structural configuration and properties of siderophores have revealed their vast affinity for iron. All siderophores differ from each other; nonetheless, they share a common conserved structure with a similar functional unit and show an identical pattern of binding to other molecules, i.e., transferrin and lactoferrin. Siderophores typically consist of a peptide backbone that interacts with receptors present in the outer membrane of the cell surface [107]. The hydroxamate siderophores are more structurally complex and hydrophilic. However, denticity plays a more critical role in their affinity toward iron. Most siderophores exhibit a hexadentate structure that allows six coordination sites for ferric ions [10]. An example of hexadentate siderophore is dihydroxylbenzoylserine trimer. It is commonly produced from enterobactin and exhibits preorganized metal-binding via macro cyclization [108].

It has been revealed that the hexadentate siderophores usually have a higher affinity for Fe (III) than tetradentate siderophores. Each of their molecules contains three bidentate ligands fused to form a hexadentate complex. This characteristic also reduces entropic changes during the chelation of a single ferric ion, as compared to the bidentate siderophores, which have only two to three ligand molecules $[8,10]$. The denticity of siderophores also differs depending on their architecture, and varies from linear dimer to trimer, or cyclic trimer. The cyclization of siderophores, related to the TAFC and enterobactin groups, enhances stability and helps them to resist enzyme degradation [38].

Siderophore structure also varies based on the presence of different functional groups. According to Renshaw et al. [109], fungal siderophores are usually formed by the basic unit $\mathrm{N} \delta$-acyl-N $\delta$-hydroxyornithine, i.e., L-isomer of N5-hydroxy-N5-acetylornithine. These siderophores are derivatives of L-ornithine, except for Neurospora crassa siderophore. Neurospora crassa, obtains a siderophore from neurosporin [51]. All siderophores produced by fungi belong to the hydroxamate group, except the polycarboxylate rhizoferrin. It was 
revealed by Huschka et al. [110] that the geometrical stability of any siderophore complex depends mainly on the kind and number of its $\mathrm{N}$-acyl residues surrounding the iron coordination center. Well configured stable L-cis ferrichrome siderophores have been identified in Aspergillus quandricinctus, Neurospora crassa, and Penicillium parvum.

The mechanism of siderophore transport is specific or well defined in fungi, which may use multiple transport systems or produce more than one siderophore at a time for efficient recruitment and transportation of metal ions. For example, Howard [15] reported that Agaricus bisporus has various transport systems for FSR and FRC, while $N$. crassa has different recognition sites for CPG and the ferrichrome-type siderophore system. Saccharomyces cerevisiae retains significant amounts of Fe-chelating molecules, termed as siderophores, in its cell wall and periplasmic space. Under Fe-deficient condition, there is the expression of very high levels of three mannoproteins (FIT1p, FIT2p, and FIT3p) commonly regarded as facilitators of Fe-transport [111]. Siderophore-Fe chelators improve protein retention in the cell wall, whereas deletion of related genes controlling the mannoproteins fit1, fit2, and fit 3 reduces ferrichrome and ferrioxamine uptake by $50 \%$. Fe-transport of $S$. cerevisiae is expressed into two genetically separate systems known as reductive and nonreductive systems [29]. The two-step reductive system operates at the plasma membrane level, where the reduction of Fe III (oxidized) into Fe II (reduced) is done by a ferrous-specific complex also known as the high-affinity transporter [112,113].

\subsection{Ferric Reductase Enzymes (FRE)}

The ferric reductase enzymes (FREs) are metalloreductases encoded by FRE1 and FRE2 genes expressed on the plasma membrane, reducing or oxidizing iron and copper $[114,115]$. These reductases are integral membrane proteins (multiple) and possess binding sites for Fe, coenzymes (FAD, NADPH), and cytochrome (b-types) [116]. Saccharomyces cerevisiae exhibited reductases in different forms such as FRE1, 2, 3, 4, 5, and 6 under iron-deficient conditions, and expressed FRE1 and 7, under copper depleted conditions. Fre3p was expressed on the plasma membrane and showed siderophore reductase activity, while Fre6p was located on a vacuolar membrane and involved in reductive export of iron into the cytosol. Initially, ferric citrate reductases (Fre1 and Fre2p) of yeast are characterized by broad substrate specificity and Fe uptake from many ferric sources. Siderophores bind ferric iron with high affinity and convert ferric ion into a ferrous ion, allowing transport by a specific ferrous ion transporter (Figure 5).

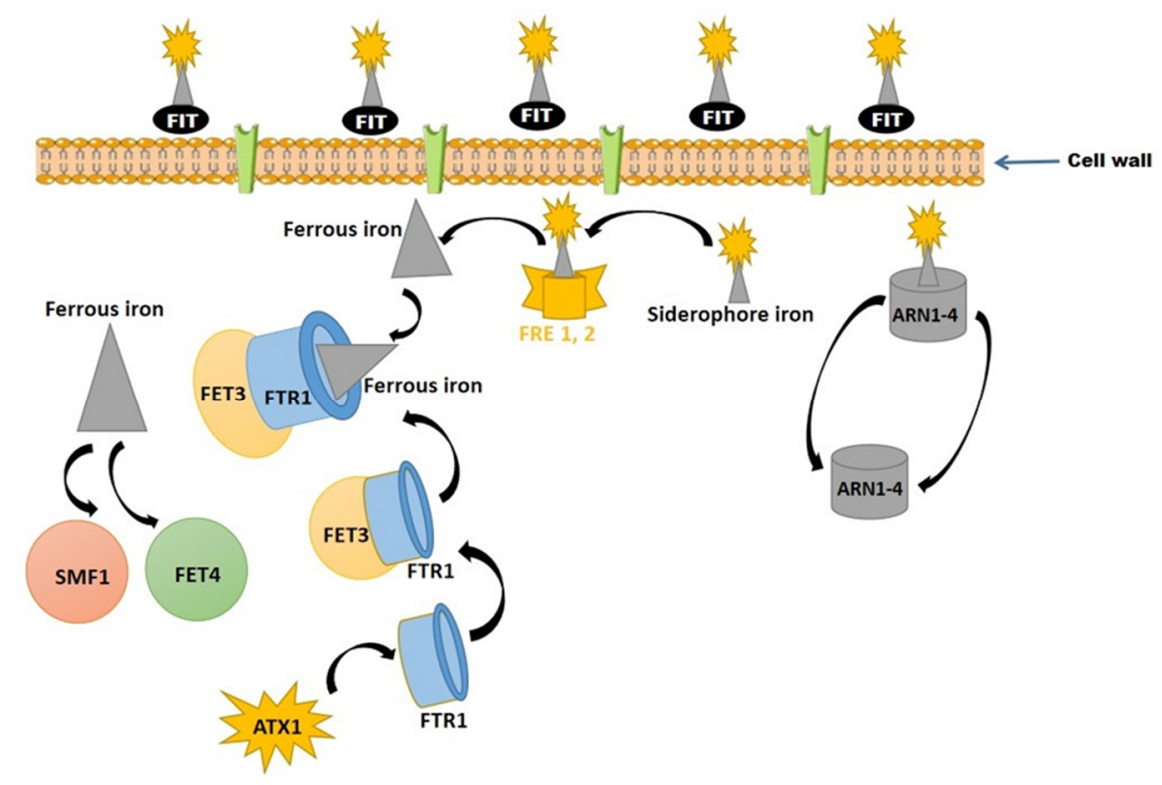

Figure 5. Mechanisms of ferric ion (Fe III) transport in the yeast cell, and subsequent transformation into ferrous ion (Fe II). 
The plasma membrane of $S$. cerevisiae is bounded by a porous cell wall, providing the shape of the cells, protecting them from osmotic lysis, and preventing the entry of too large macromolecules. The siderophore-iron retention proteins (FIT mannoproteins) of the cell wall facilitate iron retention with siderophores and do not require siderophore uptake. In a few cases, siderophores cross the cell wall via nonspecific pores. FRE reductases (FRE1,2) reduce Fe (III) into Fe (II) before uptake, and reduced iron is taken up through high-affinity ferrous iron transporters (Fet3p and Ftr1p complex) or low-affinity iron transporters (Fet4 and Smf1). However, the Fet3p requires copper for optimum activity [29].

Fre1p and Fre2p catalyze the reduction of several iron-siderophore chelates, including ferrichrome and ferrioxamine B [117]. Fre3p encodes a plasma membrane reductase that catalyzes the reductive uptake of iron bound with hydroxamate siderophores, and Fre $4 p$ specifically catalyzes the reductive uptake of di-hydroxamate rhodotorulic acid-iron [118]. The standard reduction potentials of physiological reductants such as NADPH are lower than those of ferric siderophore complexes, which are kinetically unfavorable on the cell surface. However, by coupling reduction of ferric-siderophore with competitive ligand exchange with a ferrous iron-specific chelator at lower $\mathrm{pH}$ in hydrophobic environments, the reduction potential can be changed into the level of physiologic reductants [10,119]. Therefore, in vivo ferric siderophores are reduced into ferrous ions at reduced $\mathrm{pH}$ in a lipid rich environment. Similarly, transferrin, a high-affinity iron-binding glycoprotein, reduces ferric ion into ferrous ion and removes the reduced form of iron.

\subsection{Multicopper Permease}

Multicopper permease (Ftr1p) is a high-affinity transport complex responsible for transporting reduced forms of iron [120]. The apparent $\mathrm{Km}$ of the high affinity enzyme complex is $0.2 \mu \mathrm{M}$ [121] and allows transport at low iron concentration. The ferrous iron is oxidized by Fet3p and requires molecular oxygen [122,123]. The ferric iron is transported into the cytosol via the Ftr1p permease. The oxidase reaction is copper-dependent, and four copper ions are inserted into Fet3p during post-translation in the secretory pathway on the post-Golgi compartment. The copper chaperone Atx1p is responsible for binding and transporting copper to Ccc2p [124]. The copper transporter pumps copper into the post-Golgi vesicle lumen [125]. Both proteins are necessary to maintain adequate cellular copper levels and functioning secretory pathways [126]. These copper-binding proteins, Atx1p and Ccc2p, are synthesized during iron deprivation and not copper deficiency, indicating Fet3-dependent iron uptake. Assembled complexes (Fet3p and Ftr1p) of proteins are retained by quality control systems in the endoplasmic reticulum, if expressed in the absence of their protein partner [127]. The process of ubiquitin-mediated endocytosis rapidly degrades the Fet3p/Ftr1p complex in the presence of high levels of iron [127].

\subsection{Siderophore-Iron Transporters}

Most fungi synthesize and secrete siderophores and small organic compounds that specifically bind with iron molecules with high affinity [7]. Fungal siderophores bind iron with dissociation constants $\left(10^{-29} \mathrm{M}\right)$, showing greater affinity than any iron-binding ligand in the biological systems. Hsiang [128] reported that all fungi express a nonreductive uptake system specific to siderophore iron chelates. Fungi express transporters with specificity for siderophores secreted by other species of fungi. When the siderophore is abundant, the reductive system of transport can catalyze the uptake of siderophore-bound iron. More than $50 \%$ of genes are transcriptionally activated under iron-deprived conditions and are involved in the uptake of iron chelators. The evolution of these uptake systems helps fungi and other microorganisms to compete during the limited availability of iron. 


\section{Biotechnological Applications of Siderophores}

\subsection{Treatment of Infectious Diseases and Anticancer Activity}

Siderophores can be used for the treatment of thalassemia $[129,130]$, a disease associated with inherent blood disorder due to abnormal hemoglobin formation. Many studies have shown that compounds such as desferrioxamine B (DFO) are used to reduce this disorder [131-134]. Rhodotorulic acid, a fungal siderophore, has been investigated as an alternative to DFO for iron and aluminum overload [135]. The mechanism of rhodotorulic acid is similar to the iron excretion of DFO, but increases zinc excretion, resulting in toxicity at the administration site [136]. DFO and other hydroxamate siderophores have been used to treat cancer, malaria actinide contamination, and other infectious diseases [137,138]. DFO was also reported for treatment of acute lymphoblastic leukemia by Estrov et al. [139]. Vergne et al. [140] reported that several other siderophores exhibit anticancerous and antitumor activity. For example, triornicin fungal siderophore, produced by Epicoccum purpurascens has an inhibitory effect on tumors in mice [46]. For treating infections, siderophore transport/uptake research can enhance movement of the drugs into the microbial cell conjugated with the siderophore-drug [140,141]. Actinides are radioactive elements known as potent carcinogens. Siderophores and their analogs may enhance the excretion and removal of actinides [142]. However, siderophore research in the medical field is still in progress. Most studies have been concentrated on siderophores of bacterial origin, mainly DFO, and on the siderophore analogs hydroxypyridinones.

\subsection{Application of Siderophore as Drug Delivery Agents}

Siderophore combined with antibiotic are used as a 'Trojan horse' for targeted drug delivery (Figure 6). Using siderophore receptors, this method enables antibiotic transfer across the membrane. Escherichia coli was treated with a solution of two arthrobactincarbacephem conjugates that were created [143]. A siderophore cephalosporin conjugate was examined against several pathogenic bacteria such as Pseudomonas aeruginosa and E. Coli [144]. In addition, simultaneous treatment with conjugates containing hydroxamic and catechol resulted in bacterial growth inhibition. The sideromycins, which are connected to lorabid or ciprofloxacin, are also of interest [145]. Sideromycins-lorabid conjugate invades the periplasm, whereas sideromycins-ciprofloxacin attacks the cell wall. Staphylococcus aureus growth was effectively inhibited by sideromycins. Pyochelin-norfloxacin was another siderophore conjugate compound investigated [146]. Siderophore analogues were developed and connected to an antibiotic-norfloxacin. Among four conjugates, two were found effective against $P$. aeruginosa. A vanchrobactin-norfloxacin conjugate, which demonstrated antibacterial properties against $V$. anguillarum and its variants, is another example of siderophore analogs [147]. Some siderophore-antibiotic conjugates, however, have been shown to promote bacterial growth. For example, Mycobacterium smegmatis was not affected by spermexatol-carbacephalosporin conjugates [148]. 


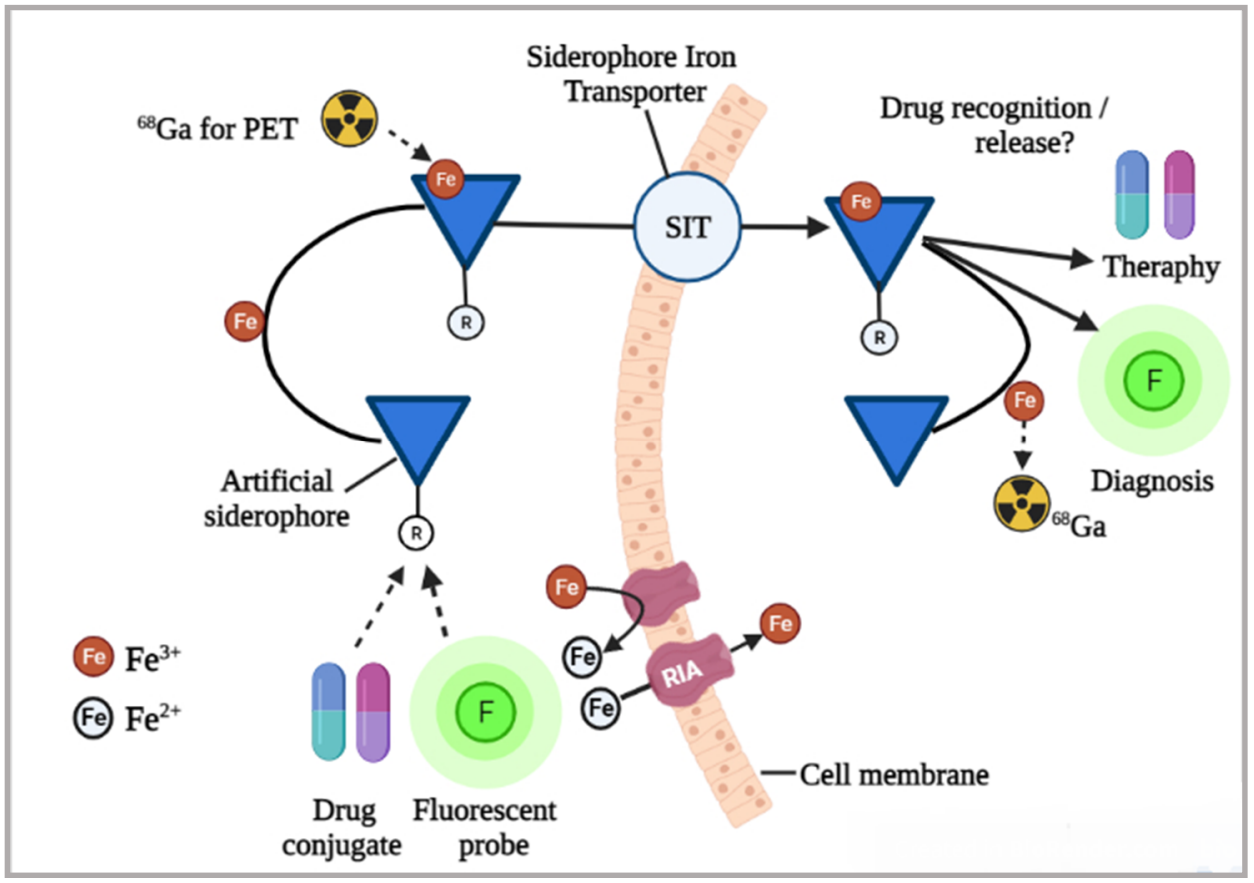

Figure 6. Siderophores for medical applications. The use of different siderophores (natural, artificial, and modified) linked to drugs or fluorescent probes, and ${ }^{68} \mathrm{Ga}$ radiolabeled for molecular imaging and/or curative practices. Siderophores facilitated intracellular absorption potentially allows diagnosis through the use of fluorescent or radioactive signal transduction or therapy by introducing antifungal drugs, thus obeying a trojan horse strategy. The siderophores' metabolic path and translation target is shown by solid line arrows. Substitution of Fe with ${ }^{68} \mathrm{Ga}$ (for PET) or drug molecules-or fluorescent probes-siderophores conjugate is indicated by dotted line arrows (modified and adapted from Petrik et al. [149].

\subsection{Application of Siderophores in Vaccine Development}

A vibriobactin analogue either connected to bovine serum albumin (BSA) or ovalbumin (OVA) was reported to stimulate the production of antibodies in a mouse model [150]. Based on a murine model of an uropathogenic E. coli (UPEC), conjugates of siderophores and antigens were recently exploited for the development of vaccines against urinary tract infections (UTIs) [151]. A decrease in bacterial concentration when mice were given siderophore-cBSA (aerobactin-cationized bovine serum albumin) conjugates, indicated protection via adaptive immunity [152]. Other studies have shown the importance of Fe transport receptors in pathogenic bacteria as vaccine components [153]. An assessment of E. coli (O157:H7) siderophore receptors, as well as porin proteins, was carried out on cattle. Two vaccine doses were found to reduce the bacterial prevalence in cattle [154]. As a potent component of vaccine, FhuD receptor of $S$. aureus was examined in another study. Because of the absence of conformational alteration, FhuD-ferrichrome was exploited as the model vaccine antigen [155].

\subsection{Application of Siderophores in Diagnostics}

\subsubsection{Radiolabeled Siderophores for Imaging Fungal Infections}

Present diagnostic methods such as computed tomography (CT) have severe limitations regarding specificity and sensitivity. For instance, any radiological indication can be associated with fungal infection in CT; thus, novel and better diagnostic methods are required for invasive fungal infections [156]. Siderophore iron transporters (SITs) are potential targets of molecular imaging methods due to their higher upregulation during fungal infection, substrate specificity, and radiolabeled substrate accumulation in the target cell after their energy-driven uptake (Figure 6). In addition, lower molecular mass and 
high hydrophilicity of siderophores lead to better circulation in infected tissues, speedy clearance from nonspecific tissues and elimination through renal excretion. Another vital characteristic of SITs is the possibility of substituting Fe in the siderophores with an Femimicking radionuclide. Gallium-68 is a diamagnetic isosteric substitution for $\mathrm{Fe}^{3+}$ that has been used to describe siderophore complexes extensively [149].

Using only microgram of the siderophore, radiolabeling of a variety of desferrisiderophores with gallium-68 can be achieved, as shown by proof-of-concept experiments [157,158]. Aspergillus fumigatus absorption of the siderophore was elevated under iron-deficient conditions and could be inhibited when there was an abundant siderophore or sodium azide, showing that the uptake is selective and energy-dependent. Using PET (Positron emission tomography)/CT technology, pulmonary infection caused by A. fumigatus was imaged in a rat model, which revealed a significant buildup of $\left[{ }^{68} \mathrm{Ga}\right] \mathrm{Ga}$-triacetyl fusarinine $C$ (TAFC) in the fungal-infested areas. In sterile inflammations and tumour cells, a considerable accumulation of $\left[{ }^{68} \mathrm{Ga}\right] \mathrm{Ga}-\mathrm{TAFC}$ was not observed [159]. It was also shown that the use of siderophores is specific to species to a certain level.

Some in vitro research has shown significant uptake of $\left[{ }^{68} \mathrm{Ga}\right] \mathrm{Ga}$-TAFC by Fusarium solani, Rhizopus oryzae, and A. fumigatus, but negligible uptake by A. flavus, Candida albicans, A. terreus, or the bacteria Klebsiella pneumoniae, P. aeruginosa, and $S$. aureus. In contrast, $A$. fumigatus showed the highest uptake of $\left[{ }^{68} \mathrm{Ga}\right]$ Ga-desferrioxamine-E (DFO-E), followed by $A$. terreus, F. solani, R. oryzae, A. flavus, and the bacterial species S. aureus [159]. Altogether, TAFC seems to be fungal-specific in comparison to DFO-E. Therefore, ${ }^{68} \mathrm{Ga}$-labeled siderophores, particularly $\left[{ }^{68} \mathrm{Ga}\right] \mathrm{Ga}-\mathrm{TAFC}$, have great potential for imaging invasive A. fumigatus infections in patients [149].

Chemical modification of siderophores has been designed for new promising applications. For example, a hybrid imaging compound may be created by binding fluorescent dyes, allowing PET/CT with gallium-68 and optical imaging [149]. To study TAFC identification in A. fumigatus by the MirB transporter, initial efforts were undertaken to chemically alter it with positive, negative or neutral charged functional groups [160]. Even without inhibiting fungal uptake, chemical alterations were possible, with encouraging results coming from the diacetylated version of fusarinine $C$ (DAFC), in which functional groups were used to change the free amine. In order to explore the hybrid imaging concept, fluorescent dyes were combined to DAFC based on these results [161]. Using the optical signals, these fluorescent siderophores enable image-guided approaches, such as bronchoscopy or surgical probing. Furthermore, such compounds can be applied for fluorescent microscopy. Specifically, a FsC-Cy5.5 conjugate was used to image the skin infections resulting from Trichophyton rubrum [162].

\subsubsection{Diagnostics of Siderophore from Urine}

The rapid clearance of $\left[{ }^{68} \mathrm{Ga}\right] \mathrm{Ga}-\mathrm{TAFC}$ through the renal system limits the use of PET to detect infections in the kidney or bladder. These results, instead, sparked research into the use of TAFC as a urine biomarker to diagnose invasive A. fumigatus infections. Clinical trials [163] and clinical samples [164] both yielded promising findings. However, additional research is required to validate this strategy prior to its application in the clinic. Moreover, the mass spectrometry approach applied is not often practiced in diagnostic labs. Nonetheless, the presence of TAFC in aspergillosis patients demonstrates that the siderophore system is activated in human infections [149].

\subsection{Bioremediation of Metal Polluted Environments}

Metals have played a vital role in the development of human civilization. However, manufacturing, sludge application, nuclear power plants and mining have caused a serious increase of heavy metal pollution in the environment [165]. In particular, soil heavy metal pollution has become one of the environmental problems of global concern. Siderophores have a strong solubilizing effect on a variety of metals such as $\mathrm{Cr}, \mathrm{Cu}, \mathrm{Ni}, \mathrm{Pb}, \mathrm{Zn}$ and the actinides $\mathrm{Th}^{4+}, \mathrm{U}^{4+}$ and $\mathrm{Pu}^{4+}$ [166]. For this reason, siderophores can contribute to the 
bioremediation of heavy metal contaminated soil. Although siderophores are mainly used to chelate $\mathrm{Fe}^{3+}$, they can be used in the detoxification process of heavy metal pollutants by combining a variety of toxic metals. The ability of siderophores to chelate heavy metals mainly depends on the stability constant of the siderophore and the metal to form a complex [167]. The use of siderophores for remediation of heavy metal pollution has the advantages of low cost, high efficiency, and no environmentally hazardous collateral. In recent years, there has been an increasing interest in the application of siderophores in metal bioremediation. Phytoremediation is an emerging and practical technology in the field of bioremediation, but heavy metal stress can interfere with the absorption and utilization of iron by plants, cause iron deficiency, affect chlorophyll synthesis, turn young leaves yellow, and hinder plant growth. Siderophore-producing rhizosphere fungi are a group of plant rhizosphere growth-promoting microorganisms whose siderophore products can react with iron-containing minerals in the soil to generate soluble $\mathrm{Fe}^{3+}$-siderophore chelates, which promote the dissolution of $\mathrm{Fe}^{3+}$ in the soil [168]. These rhizosphere fungi can provide nutrients (especially iron) to plants under heavy metal stress, by inducing selective absorption by plants of the different metals available in the environment. In fact, siderophores combined with iron can effectively be absorbed by plant cells, whereas they cannot easily enter the cells when combined with other heavy metals. Therefore, siderophores can significantly alleviate the stress caused by metal toxicity and promote plant growth [169]. In addition, studies have shown that siderophore-producing rhizosphere fungi can maintain their growth-promoting effects on plants in heavy metal polluted soil because siderophores can alleviate the inhibitory effect of heavy metals on the synthesis of plant growth hormones, such as indoleacetic acid, by fungi [170]. Siderophores produced by rhizosphere fungi can chelate with $\mathrm{Fe}^{3+}$ to inhibit the absorption of iron by plant pathogens, thus reducing the activity of pathogens, protecting plants from diseases and promoting plant growth [171]. In addition to their growth-promoting effect to improve the biomass of plants, fungal siderophores can also improve the activity of heavy metals in the rhizosphere environment and promote the absorption and accumulation of heavy metals in plants. The activity of heavy metals in the plant rhizosphere is an important factor that determines whether large amounts of heavy metals can be absorbed by plants [172]. The siderophores produced by rhizosphere fungi can combine with heavy metal ions in the soil to form a soluble heavy metal-siderophore chelate, thereby improving the activity of heavy metals in the rhizosphere environment, increasing the absorption and accumulation of heavy metals by plants, and improving the efficiency of phytoremediation [173]. Dahlheimer and colleagues used siderophores to react with oxides containing the heavy metal ions $\mathrm{Pt}^{4+}$ and $\mathrm{Pd}^{2+}$ and found that siderophores can form soluble chelates with $\mathrm{Pt}^{4+}$ and $\mathrm{Pd}^{2+}$, thus increasing the solubility of $\mathrm{Pt}$ and $\mathrm{Pd}$ [174]. Hong et al. reported the in vitro dissolution of copper and zinc via siderophores produced by the fungal species Fusarium solani [175]. Other studies have also confirmed that siderophores can promote the dissolution of many common heavy metals, and even metalloids, from their minerals. For instance, siderophores can promote the dissolution of manganese-containing minerals such as $\mathrm{Mn}_{3} \mathrm{O}_{4}$ [176]. At the same time, heavy metals can influence siderophore-producing microorganisms, and the total amount of siderophores increased in copper-contaminated sites [177]. Siderophores and heavy metals can also be stored in fungi after chelation. For example, in soil contaminated by metals, Hypocrea lixii can secrete siderophores to accumulate copper and zinc in the biomass [78].

The motor manufacturing industry, sewage sludge, vehicle emissions, and mining are common contributing sources for metal pollution [178,179]. Neptunium and plutonium are man-made actinides present in the environment as pollutants due to the testing of nuclear power stations and weapons production, posing a significant environmental hazard [180]. Siderophores are effective for the solubilization of actinides [181] and form stable tetravalent actinides. They also play a significant role in the mobilization of other metals, including zinc, copper, lead, and cadmium [182,183]. Siderophore-producing microorganisms are abundant in soil [184] and affect the bioavailability of metals and radionuclides present in the environment $[183,185]$. Siderophores could be used to develop metal recov- 
ery or remediation of waste sites, including radioactive waste, due to their complexing ability [167].

\subsection{Plant Growth Enhancement and Biocontrol of Plant Pathogens}

Microbial siderophores provide Fe-nutrition when the bioavailability of iron is limited to enhance plant growth [186], although the mechanism of siderophore mediated Fe-nutrition is still not fully known. However, two possible mechanisms by which plants could obtain Fe from microbial siderophores have been suggested: (i) high redox potential of microbial siderophores can be reduced by the donation of ferrous in the transport system, and (ii) microbial ferric ions are transported in plant root through the apoplast where the reduction of siderophore takes place [187], with consequent ferrous accumulation in the apoplast leading to a high concentration of Fe (II) in the root [188], and (iii) siderophores of microbial origin can chelate Fe from soils and perform ligand exchange with phytosiderophores [189]. These mechanisms depend on several parameters such as concentrations of phytosiderophores, microbial source, $\mathrm{pH}$, and redox potential of root environment [186]. Schenk et al. [190] found that siderophores are a valid eco-friendly alternative to hazardous pesticides. Mycorrhizal fungi are used as biofertilizers for the enhancement of plant growth and development. Higher levels of Fe-sequestration occurred in plants associated with mycorrhizal fungi compared to nonmycorrhizal plants, suggesting that enhanced plant nutrition by mycorrhizal fungi depends on fungal siderophores [191,192]. Plant growth-promoting activities of fungi were previously investigated by Yadav et al. [193] who found that fungal species such as Trichoderma harzianum, Penicillium citrinum, and Aspergillus niger produced siderophores and increased root and shoot length of chickpeas. Siderophores play a significant role in biological control as competitors for Fe to reduce the Fe availability for the pathogens of plants [194]. Wilt diseases of potatoes caused by Fusarium oxysporum can be controlled by Pyoverdine siderophores produced by Pseudomonas sp. [195]. Apart from fungi, bacterial strains, mainly belonging to the genus Pseudomonas, have been extensively studied to improve plant growth by synthesizing siderophores or protecting the plant host from pathogens [196].

\subsection{Enzyme-Inhibiting Activity}

Siderophores are iron chelators capable of inhibiting the iron-dependent activity of enzymes by withdrawing iron. Several studies have shown that ribonucleotide reductase activity is reduced by synthetic siderophores [197] as a result of inhibition of biosynthesis of DNA. In proliferating neoplastic cells, iron delivering transferrin receptors were found to frequently occur on the cell surface and enhance iron requirement by the cell. Inhibition of iron supply by the siderophores reduced the growth of neoplastic cells [132,197]. Therefore, siderophores can be used as inhibitors of cell proliferation and help to design drugs with anticancer activity.

\subsection{Computational Approaches for the Application of Siderophores}

With the advancement in bioinformatics and computational approaches, it has become easier to explore gene clusters for siderophore biosynthetic pathways and their interactions with other proteins and peptides. Siderophores are complex structures of nomproteinogenic amino acids with huge structural variations. These structural variations make siderophores suitable for various applications. Computational and bioinformatics tools help to predict the affinity and properties of siderophores. Norine is a bioinformatics platform that is an easily available unique resource devoted to elucidating the structures of nonribosomal peptides. This tool helps to identify newly discovered siderophores, whether new nonribosomal peptides or variants of an existing family. Similarly, AntiSMASH (antibiotics \& Secondary Metabolite Analysis Shell) is an internet-based bioinformatics tool which finds the region in plants, fungi, and bacteria responsible for the biosynthesis of secondary metabolites. AntiSMASH allocates a functional "siderophore" label for biological gene clusters which contain the lucA/lucC gene family specific to the siderophores biosynthetic 
pathways, which further helps to predict the siderophores activity [198]. These tools help to derive siderophore biosynthesis pathways and make them accessible for reference. The prediction of biosynthetic pathways for the production of siderophores facilitated the discovery of novel and exclusive siderophores such as thioquinolobactin [199]. Molecular dockings and dynamic simulations are additional techniques for analyzing the interaction of siderophores with other proteins. Samsonov et al. [200] successfully applied molecular docking and molecular dynamic simulations to analyze the potential binding interaction between nine bacterial siderophores and lipocaline, a member of human serum a1-acid glycoprotein. A comparative study of computational and experimental results indicated that serum a1-acid glycoprotein can effectively bind with the Fe-BisHaCam and petrobactin, which shows that serum a1-acid glycoprotein can be putatively involved in the nullification of bacterial infections by capturing iron-chelating compounds. Furthermore, Xie et al. [201] explored bioinformatics approaches such as mutasynthesis, genome mining, and activity screening to synthesize fluorinated amychelin fluoroamychelin I siderophores. The resulting fluorinated fluoroamychelin I was able to rescue Caenorhabditis elegans from Pseudomonas aeruginosa-mediated killing with greater efficiency than traditional antibiotics, including meropenem and ceftazidime. The study showed a successful implementation of bioinformatics approaches for the production of synthetic antibacterial compounds by modifying siderophores. In addition to these, Flux balance analysis (FBA) is a computational tool that is frequently used in metabolic engineering for the improvement of production yield. Siderophores are small-sized metal chelators that are usually secreted in very small quantities by their native microbial hosts. FBA can be applied to predict media composition to enhance production yield that can be further verified experimentally. Recently FBA has been applied to improve the heterologous expression of siderophores by E. coli K-12 MG1655 [202]. In conclusion, computational and bioinformatics approaches are helpful to identify novel siderophores, their biosynthetic pathways, and biological activities. Furthermore, these techniques are applicable to modify siderophore structures in order to improve their bioactivity and even their production yield.

\section{Importance of Siderophores in Nature}

\subsection{Weathering of Soil Minerals}

Soil microbes produce siderophores that can stimulate the dissolution of insoluble phases minerals $[203,204]$. Several mechanisms for siderophore-stimulated Fe dissolution have been proposed [205]. In general, the Fe (III) and siderophore complex forms on the mineral surface and is subsequently transported into the adjacent soil solution, where it is accessible for absorption by microbes and plants $[203,206]$. Because siderophores and Fe form more permanent complexes, their influence on soil mineral weathering may be greater than low molecular mass organic acids (LMMOAs). Siderophores and Fe (III) form 1:1 complexes with K constants ranging from of 1030 to 1052 [207], whereas, with Fe (III), oxalic acids have constants of $\mathrm{K}=10^{8}$ and citric acids have constants of $\mathrm{K}=10^{12}$ [208]. Nevertheless, when both siderophores and LMMOAs are present, the mineral dissolution rate is increased more than when the solitary siderophore is present [209]. Many studies have reported microbial siderophore involvement in dissolution of Fe minerals due to their relevance in weathering and soil formation. In a study, researchers revealed the effectiveness of hydroxamate siderophores formed by Suillus granulatus in dissolving goethite. Due to the continual synthesis of siderophores by S. granulatus, significant amounts of $\mathrm{Fe}\left(10^{9} \mathrm{~mol} \mathrm{~m} / \mathrm{h}\right)$ were mobilized [210]. Additionally, Sokolova et al. [211] found that fungal siderophores belonging to the family of ferrichrome, including ferricrocin and ferrichrome, contributed to altering the surface structure of biotite and promoting its dissolution in forest podzolic soil.

Compared to a synthetic siderophore, the presence of siderophore-producing actinobacteria, such as Arthrobacter and Streptomyces, significantly enhanced the Fe dissolution from hornblende [206]. Phytosiderophores have been shown to elevate Fe-containing mineral dissolution, thus contributing to weathering processes of minerals, for example goethite 
and ferrihydrate [212]. According to Reichard et al. [213], the highest goethite dissolution rate of $1.7 \mathrm{nmol} \mathrm{m} / \mathrm{h}$ at $\mathrm{pH} 6$ was obtained in the presence of $2^{\prime}$-deoxymugineic acid (phytosiderophores). The transporter genes expression of Fe-phytosiderophore in barley has recently been shown to improve its capacity to remove Fe from soil minerals [214].

\subsection{Oceanic Biogeochemical Cycle of Fe}

Trace metal biogeochemical cycling in the oceans has become a significant source of concern. Fe has gained the most attention out of all the trace metals found in marine waters since it is a critical micronutrient for marine life and affects phytoplankton production and community structure [215]. Marine bacteria are responsible for most organic Fe chelators found in seawater and hence play a central part in the Fe biogeochemical cycle in the ocean [216]. These bacteria compete for Fe with phytoplankton by creating several forms of siderophores, which significantly influence the abundance and solubility of Fe in the ocean [217]. In marine siderophores, either citrate or b-hydroxyaspartate contributes hydroxyl-carboxylate functional groups $[198,218]$. Siderophores contribute to the photochemical cycle of Fe in surface water by producing complexes of Fe (III)-siderophore that improve the availability of Fe for the phytoplankton $[219,220]$. Ferrioxamine $G$ was discovered to be broadly dispersed in surface waters across the Atlantic Ocean, while ferrioxamine $\mathrm{E}$ was shown to have a more diverse distribution at different depths. These data imply that marine siderophores play a significant part in the biogeochemical cycle of Fe by elevating the abundance, as well as the availability, of Fe in the Atlantic Ocean [221,222].

\section{Conclusions}

Iron is an essential element for all living organisms. Fungi acquire iron from extracellular environments by secreting siderophores, which are low molecular weight, iron-binding molecules. Siderophores play a significant role in the iron homeostasis of fungi, which are similar to bacteria and plants for the mobilization of extracellular iron. Considerable progress has been made on siderophore uptake research and understanding iron assimilation mechanisms in S. cerevisiae. However, much more remains to be explored regarding biosynthetic pathways, iron assimilation, and regulation. In this regard, further studies based on genome sequence analysis of fungi and siderophore-mediated iron acquisition in a wide range of fungal species are still needed. Apart from fungal siderophore-type descriptions, several unexplored aspects need to be elucidated, including extracellular excretion mechanisms, details of the siderophore biosynthetic pathways, intracellular iron release, iron metabolism and storage of iron. Iron requirements of fungi open up new research areas for the development of novel antifungal treatments such as iron chelation therapy. Functional studies of siderophores may reveal novel non-ribosomal peptide synthetases that can open the way for the development of new compounds with pharmaceutical value. In fungal species, siderophore-mediated iron uptake is essential for survival as free-living organisms and for establishment of commensal and pathogenic relationships.

Studies conducted on low Fe bioavailability and siderophore activity in different environments may enhance our understanding of siderophore ecology and functions. Metagenomic analyses provide an excellent platform to clarify the structural diversity of siderophores among different fungal species. The knowledge of siderophore biosynthesis and utilization mechanisms in each fungal species could be essential for eradicating pathogenic fungi hiding and replicating in host macrophages.

With the advent of genome sequencing technologies and concurrent omics analysis, there has been a vast increase in our knowledge of siderophore biosynthesis over the past two decades. The first step was identifying gene clusters acting as sources of siderophores via bioinformatics. Prediction of substrate specificity combined with algorithms parsing metabolomic data to link the clusters to corresponding compounds may constitute the following steps. For each step, multiple new techniques have been developed in the last few years. In silico genome mining is an efficient high-throughput approach to uncover potential nonribosomal peptide synthetases (NRPS) genes. Analytical pipelines linking 
genomics with other omics data have been developed and can reveal much information on the synthesis of such natural products. Computational tools coupled with genome mining provide efficient methods to identify and characterize biosynthetic gene clusters BGCs [223]. Natural product research and siderophore research have been concentrated on bacterial species, and there is an obvious bias in data availability and algorithm development for fungal research. Therefore, it is essential to consider the differences and test the relevance of already developed tools on fungal data before blind usage. It would be ideal to generate, collect, and analyze fungal NRPS data, and particularly reorganize siderophore-producing data for fungal siderophore identification. The lack of such curated data is currently a shortcoming in developing and training prediction/classification models for fungal siderophores. Algorithms for the identification of siderophore-producing BGCs integrated with high-throughput proteomic and metabolomic product detection techniques can lead to the discovery and characterization of novel siderophores.

With the help of computational approaches, inhibitors can be designed against siderophore biosynthetic pathway enzymes and siderophore transporter proteins by applying the principles of structure-based drug design and/or fragment-based drug design. Similarly, the structure-based pharmacophores for these catalytic enzymes can be predicted and searched against the chemical databases for compounds suitable as siderophore biosynthetic enzyme inhibitors. In contrast, biosynthetic pathway enzyme competitive inhibitors can be identified using the shape and structural information of enzyme substrates. Applying shape-based and fingerprint-based similarity searches allows suitable competitive enzyme inhibitors to be predicted from chemical databases. In addition, a drug repurposing approach can be applied to find existing drugs with antifungal activity. This approach reduces drug discovery cost to a great extent, with a higher success rate than other approaches.

Author Contributions: L.P. conceived the idea and coordinated the contribution of all coauthors. L.P. and X.W. wrote large part of the manuscript. All authors (L.P., X.W., D.S., X.S., V.K., A.S., K.T., P.W.R., R.R.) significantly contributed to the work by writing part of the manuscript, preparing figures and tables, reviewing and editing. All authors have read and agreed to the published version of the manuscript.

Funding: This research received no external funding.

Institutional Review Board Statement: Not applicable.

Informed Consent Statement: Not applicable.

Data Availability Statement: Not applicable.

Conflicts of Interest: The authors declare no conflict of interest.

$\begin{array}{ll}\text { Abbreviations } \\ \text { TAFC } & \text { triacetyl fusarine C } \\ \text { FSC } & \text { fusarine C } \\ \text { FSR } & \text { fusarinine } \\ \text { CPG } & \text { coprogen } \\ \text { Frr } & \text { ferricrocin } \\ \text { FRC } & \text { ferrichromes } \\ \text { Fsg } & \text { fusigen } \\ \text { NRPS } & \text { nonribosomal peptide synthetases } \\ \text { SIT } & \text { siderophore-iron transporter } \\ \text { Estb } & \text { esterase } \\ \text { FIT } & \text { facilitator of iron transport } \\ \text { FREs } & \text { ferric reductase enzymes } \\ \text { Fet } & \text { ferrous iron transporter } \\ \text { DFO } & \text { desferrioxamine B }\end{array}$




\section{References}

1. Winkelmann, G. Importance of siderophores in fungal growth, sporulation and spore germination. Front. Mycol. 1991, 1991, 49-65.

2. Ducklow, H.W.; Oliver, J.L.; Smith, W.O. The Role of Iron as a Limiting Nutrient for Marine Plankton Processes. 2018. Available online: pal.lternet.edu/docs/bibliography/Public/259lterc.pdf (accessed on 21 April 2021).

3. Mustoe, G.E. Biogenic weathering: Solubilization of iron from minerals by epilithic freshwater algae and cyanobacteria. Microorganism 2018, 6, 8. [CrossRef]

4. Paul, A.; Dubey, R. Characterization of protein involved in nitrogen fixation and estimation of Co-factor. Appl. J. Curr. Res. Biosci. Plant Biol. 2015, 2, 89-97.

5. Martinez, J.L.; Delgado-Iribarren, A.; Baquero, F. Mechanisms of iron acquisition and bacterial virulence. FEMS Microb. Rev. 1990, 7, 45-56. [CrossRef]

6. Wang, X.; Pecoraro, L. Analysis of soil fungal and bacterial communities in Tianchi Volcano crater, northeast China. Life 2021, 11, 280. [CrossRef]

7. Neilands, J. Siderophores: Structure and function of microbial iron transport compounds. J. Biol. Chem. 1995, 270, 26723-26726. [CrossRef]

8. Khan, A.; Singh, P.; Srivastava, A. Synthesis, nature and utility of universal iron chelator-Siderophore: A review. Microbiol. Res. 2018, 212-213, 103-111. [CrossRef]

9. Chincholkar, S.B.; Chaudhari, B.L.; Rane, M.R. Microbial Siderophore: A State of Art. In Microbial Siderophores; Soil Biology; Varma, A., Chincholkar, S.B., Eds.; Springer: Berlin/Heidelberg, Germany, 2007; Volume 12.

10. Boukhalfa, H.; Crumbliss, A. Chemical aspects of siderophore mediated iron transport. Biometals 2002, 15, 325-339. [CrossRef] [PubMed]

11. Devireddy, L.; Hart, D.; Goetz, D.; Green, M. A mammalian siderophore synthesized by an enzyme with a bacterial homolog involved in enterobactin production. Cell 2010, 141, 1006-1017. [CrossRef]

12. Pluháček, T.; Lemr, K.; Ghosh, D.; Milde, D.; Novák, J.; Havlíček, V. Characterization of microbial siderophores by mass spectrometry. Mass Spectrom. Rev. 2016, 35, 35-47. [CrossRef]

13. Aguado-Santacruz, G.A.A.; Moreno-Gomez, B.A.; Jimenez-Francisco, B.B.; Garcia-Moya, E.B.; Preciado-Ortiz, R.E. Impact of the microbial siderophores and phytosiderophores on the iron assimilation by plants: A synthesis. Rev. Fitotec. Mex. 2012, 35, 9-21.

14. Raymond, K.; Dertz, E.; Kim, S. Enterobactin: An archetype for microbial iron transport. Proc. Natl. Acad. Sci. USA 2003, 100, 3584-3588. [CrossRef] [PubMed]

15. Howard, D.H. Acquisition, transport, and storage of iron by pathogenic fungi. Clin. Microbiol. Rev. 1999, 12, 394-404. [CrossRef] [PubMed]

16. Lawen, A.; Lane, D.J.R. Mammalian iron homeostasis in health and disease: Uptake, storage, transport, and molecular mechanisms of action. Antioxid. Redox Signal. 2013, 18, 2473-2507. [CrossRef]

17. Mech, F.; Wilson, D.; Lehnert, T.; Hube, B.; Figge, M.T. Epithelial invasion outcompetes hypha development during Candida albicans infection as revealed by an image-based systems biology approach. Cytom 2014, 85, 126-139. [CrossRef] [PubMed]

18. Crawford, A.; Wilson, D. Essential metals at the host-pathogen interface: Nutritional immunity and micronutrient assimilation by human fungal pathogens. FEMS Yeast Res. 2015, 15, fov071. [CrossRef] [PubMed]

19. Bellenger, J.P.; Wichard, T.; Kraepiel, A.M.L. Vanadium requirements and uptake kinetics in the dinitrogen-fixing bacterium Azotobacter vinelandii. Appl. Environ. Microbiol. 2008, 74, 1478-1484. [CrossRef] [PubMed]

20. Verma, V.C.; Singh, S.K.; Prakash, S. Bio-control and plant growth promotion 926 potential of siderophore producing endophytic Streptomyces from Azadirachta indica A. Juss J. Basic Microb. 2011, 51, 550-556. [CrossRef] [PubMed]

21. Ishimaru, Y.; Takahashi, R.; Bashir, K.; Shimo, H.; Senoura, T.; Sugimoto, K.; Ono, K.; Yano, M.; Ishikawa, S.; Arao, T.; et al Characterizing the role of 699 rice NRAMP5 in Manganese, Iron and Cadmium Transport. Sci. Rep. 2012, 2, 28. [CrossRef] [PubMed]

22. Ghosh, S.K.; Banerjee, S.; Sengupta, C. Bioassay, characterization and estimation of siderophores from some important antagonistic fungi. J. Biopest. 2017, 10, 105-112.

23. Schrettl, M.; Ibrahim-Granet, O.; Droin, S.; Huerre, M.; Latgé, J.; Haas, H. The crucial role of the Aspergillus fumigatus siderophore system in interaction with alveolar macrophages. Microbes Infect. 2010, 12, 1035-1041. [CrossRef]

24. Oberegger, H.; Schoeser, M.; Zadra, I.; Abt, B.; Haas, H. SREA is involved in regulation of siderophore biosynthesis: Utilization and uptake in Aspergillus nidulans. Mol. Microbiol. 2001, 41, 1077-1089. [CrossRef]

25. Arantes, V.; Milagres, A.M.F. Response of Wolfifiporia cocos to iron availability: Alterations in growth, expression of cellular proteins, Fe3+-reducing activity and Fe3+- chelators production. J. Appl. Microbiol. 2008, 104, 185-193.

26. Haselwandter, K.; Häninger, G.; Ganzera, M.; Haas, H.; Nicholson, G.; Winkelmann, G. Linear fusigen as the major hydroxamate siderophore of the ectomycorrhizal Basidiomycota Laccaria laccata and Laccaria bicolor? Biometals 2013, 26, 969-979. [CrossRef]

27. Osman, A.; Işıl, V.; Fatih, K. Microbial siderophores: Potential medicinal applications of the siderophores. J. Biotechnol. Sci. Res. $2019,6,32-40$

28. Hagen, J.B. Five Kingdoms, More or Less: Robert Whittaker and the Broad Classification of Organisms. BioScience 2012, 62, 67-74. [CrossRef]

29. Philpott, C.C. Iron uptake in fungi: A system for every source. Biochim. Biophys. Acta 2006, 1763, 636-645. [CrossRef] [PubMed] 
30. Ali, S.S.; Vidhale, N.N. Bacterial siderophore and their application: A review. Int. J. Curr. Microbiol. Appl. Sci. $2013,2,303-312$.

31. Drechsel, H.; Tschierske, M.; Thieken, A.; Jung, H.; Zähner, G.; Winkelmann, G. The carboxylate type siderophore rhizoferrin and its analogs produced by directed fermentation. J. Ind. Microbiol. 1995, 14, 105-112. [CrossRef]

32. Butler, A.; Theisen, R.M. Iron (III)-siderophore coordination chemistry: Reactivity of marine siderophores. Coord. Chem. Rev. 2010, 254, 288-296. [CrossRef]

33. Braud, A.; Geoffroy, V.; Hoegy, F.; Mislin, G.L.; Schalk, I.J. Presence of the siderophores pyoverdine and pyochelin in the extracellular medium reduces toxic metal accumulation in Pseudomonas aeruginosa and increases bacterial metal tolerance. Environ. Microbiol. Rep. 2010, 2, 419-425. [CrossRef] [PubMed]

34. Kessenbrock, K.; Plaks, V.; Werb, Z. Matrix metalloproteinases: Regulators of the tumor microenvironment. Cell 2010, 141 , 52-67. [CrossRef] [PubMed]

35. Haas, H. Fungal siderophore metabolism with a focus on Aspergillus fumigatus. Nat. Prod. Rep. 2014, 31, 1266-1276. [CrossRef]

36. Das, A.; Prasad, R.; Srivastava, A.; Giang, P.H.; Bhatnagar, K.; Varma, A. Fungal siderophores: Structure, functions and regulation. In Microbial Siderophores; Springer: Berlin/Heidelberg, Germany, 2007; pp. 1-42.

37. Baakza, A.; Dave, B.P.; Dube, H.C. Chemical nature, ligand denticity and quantification of fungal siderophores. NISCAIR 2004, 42, 96-105.

38. Winkelmann, G. Microbial siderophore-mediated transport. Biochem. Soc. Trans. 2002, 30, 691-696. [CrossRef]

39. Saha, M.; Sarkar, S.; Sarkar, B.; Sharma, B.K.; Bhattacharjee, S.; Tribedi, P. Microbial siderophores and their potential applications: A review. Environ. Sci. Pollut. Res. Int. 2016, 23, 3984-3999. [CrossRef] [PubMed]

40. Anke, H.; Kinn, J.; Bergquist, K.E.; Sterner, O. Production of siderophores by strains of the genus Trichoderma-Isolation and characterization of the new lipophilic coprogen derivative, palmitoylcoprogen. Biol. Met. 1991, 4, 176-180. [CrossRef]

41. Charlang, G.; Ng, B.; Horowitz, N.H.; Horowitz, R.M. Cellular and extracellular siderophores of Aspergillus nidulans and Penicillium chrysogenum. Mol. Cell Biol. 1981, 1, 94-100.

42. Mor, H.; Kashman, Y.; Winkelmann, G.; Barash, I. Characterization of siderophores produced by different species of the dermatophytic fungi Microsporum and Trichophyton. Biometals 1992, 5, 213-216. [CrossRef]

43. Jalal, M.A.F.; Helm, D. Siderophores of highly phytopathogenic Alternaria longipes. Biol. Met. 1989, 2, 11-17. [CrossRef]

44. Jalal, M.A.F.; Love, S.K.; van der Helm, D. N alpha-dimethylcoprogens three novel trihydroxamate siderophores from pathogenic fungi. Biol. Met. 1988, 1, 4-8. [CrossRef]

45. Hossain, M.B.; Jalal, M.A.F.; Benson, B.A.; Barnes, C.L.; Van der Helm, D. Structure and conformation of two coprogentype siderophores: Neocoprogen I and neocoprogen II. J. Am. Chem. Soc. 1987, 109, 4948-4954. [CrossRef]

46. Frederick, C.B.; Bentley, M.D.; Shive, W. Structure of triornicin, a new siderophore. Biochemistry 1981, 20, 2436-2438. [CrossRef]

47. Chowdappa, S.; Jagannath, S.; Konappa, N.; Udayashankar, A.C.; Jogaiah, S. Detection and Characterization of Antibacterial Siderophores Secreted by Endophytic Fungi from Cymbidium aloifolium. Biomolecules 2020, 10, 1412. [CrossRef]

48. Diekmann, H. Metabolic products of microorganisms 81. Occurrence and structures of coprogen B and dimerum acid. Arch. Mikrobiol. 1970, 73, 65-76. [CrossRef]

49. Emery, T. Malonichrome, a new iron chelates from Fusarium roseum. Biochim. Biophys. Acta 1980, 629, 382-390. [CrossRef]

50. Jalal, M.A.F.; Love, S.K.; van der Helm, D. Siderophore Mediated Iron (III) Uptake in Gliocladium virens: 1. Properties of cis-Fusarinine, trans-Fusarmine, Dimerum Acid, and Their Ferric Complexes. J. Inorg. Biochem. 1986, 28, 417-430. [CrossRef]

51. Eng-Wilmot, D.L.; Rahman, A.; Mendenhall, J.V.; Grayson, S.L.; Dick, V.D.H. Molecular structure of ferric neurosporin, a minor siderophore-like compound containing N $\delta$-hydroxy-D-ornithine. J. Am. Chem. Soc. 1984, 106, 1285-1290. [CrossRef]

52. Pidacks, C.; Whitehill, A.R.; Pruess, L.M.; Hesseltine, C.W.; Hutchings, B.L.; Bohonos, N.; Williams, J.H. Coprogen, the isolation of a new growth factor required by Pilobolus species. J. Am. Chem. Soc. 1953, 75, 6064-6065. [CrossRef]

53. Moore, R.E.; Emery, T. N(alpha)-acetylfusarinines: Isolation, characterization, and properties. Biochemistry 1976, 15, $2719-2723$. [CrossRef]

54. Lesuisse, E.; Raguzzi, F.; Crichton, R.R. Iron Uptake by the Yeast Saccharomyces cerevisiae: Involvement of a Reduction Step. J. Gen. Microbiol. 1987, 133, 3229-3236. [CrossRef]

55. Haselwandter, K.; Dobernigg, B.; Beck, W.; Jung, G.; Cansier, A.; Winkelmann, G. Isolation and identification of hydroxamate siderophores of ericoid mycorrhizal fungi. Biometals 1992, 5, 51-56. [CrossRef]

56. Senthilnithy, R.; De Costa, M.D.P.; Gunawardhana, H.D. The pKa values of ligands and stability constants of the complexes of $\mathrm{Fe}(\mathrm{III}), \mathrm{Cu}(\mathrm{II})$ and $\mathrm{Ni}(\mathrm{II})$ with some hydroxamic acids: A comparative study of three different potentiometric methods. J. Natl. Sci. Found. 2008, 36, 191-198.

57. Silva-Bailão, M.G.; Bailão, E.F.L.C.; Lechner, B.E.; Gauthier, G.M.; Lindner, H.; Bailão, A.M.; Haas, H.; de Almeida Soares, C.M. Hydroxamate production as a high affinity iron acquisition mechanism in Paracoccidioides spp. PLoS ONE 2014, 9 , e105805. [CrossRef]

58. Atkin, C.L.; Neilands, J.B. Rhodotorulic acid, a diketopiperazine dihydroxamic acid with growth-factor activity. Isolation and characterization. Biochemistry 1968, 7, 3734-3739. [CrossRef]

59. Muller, G.; Barclay, S.J.; Raymond, K.N. The mechanism and specificity of iron transport in Rhodotorula pilimanae probed by synthetic analogs of Rhodotorulic acid. J. Biol. Chem. 1985, 260, 13916-13920. [CrossRef]

60. Challis, G.L. A widely distributed bacterial pathway for siderophore biosynthesis independent of nonribosomal peptide synthetases. Chem. Biochem. 2005, 6, 601-611. [CrossRef] 
61. Sah, S.; Singh, R. Siderophore: Structural and functional characterization-A comprehensive review. Agriculture 2015, 61, 97-114. [CrossRef]

62. Crosa, J.H.; Walsh, C.T. Genetics and assembly line enzymology of siderophore biosynthesis in bacteria. Microbiol. Mol. Biol. Rev. 2002, 66, 223-249. [CrossRef]

63. Ravel, J.; Cornelis, P. Genomics of pyoverdine-mediated iron uptake in pseudomonads. Trends Microbiol. 2003, 11, 195-200. [CrossRef]

64. Nadia, K.; Challis, G.L. Complex enzymes in microbial natural product biosynthesis. Methods Enzymol. 2009, 458, $431-435$.

65. Hider, R. Siderophore mediated absorption of iron. Struct. Bond. 1984, 58, $25-87$.

66. Mei, B.; Leon, S.A. Molecular biology of iron transport. In Metal Ions in Fungi; Marcel Dekker: New York, NY, USA, 1994; pp. 117-148.

67. Plattner, H.J.; Diekmann, H. Enzymology of siderophore biosynthesis in fungi. In Metal Ions in Fungi; Winkelmann, G., Winge, D.R., Eds.; Decker: New York, NY, USA, 1994; pp. 99-116.

68. De Luca, N.G.; Wood, P.M. Iron uptake by fungi: Contrasted mechanisms with internal or external reduction. Adv. Microb. Physiol. 2001, 43, 39-74.

69. Ong, D.E.; Emery, T.F. Ferrichrome biosynthesis: Enzyme catalyzed formation of the hydroxamic acid group. Arch. Biochem. Biophys. 1972, 148, 77-83. [CrossRef]

70. Neilands, J.B.; Konopka, K.; Schwyn, B.; Coy, M.; Francis, R.T.; Paw, B.H.; Bagg, A. Comparative biochemistry of microbial iron assimilation. In Iron Transport in Microbes, Plants and Animals; Winkelmann, G., Winge, D.R., Eds.; VCH Weinheim: New York, NY, USA, 1987; pp. 3-34.

71. Schwyn, B.; Neilands, J.B. Universal chemical assay for the detection and 878 determinations of siderophores. Anal. Biochem. 1987, 160, 47-56. [CrossRef]

72. Anke, H.; Anke, T.; Diekmann, H. Biosynthesis of sideramines in fungi. Fusigen synthetase from extracts of Fusarium cubense. FEBS Lett. 1973, 36, 323-325. [CrossRef]

73. Calvente, V.; Benuzzi, D. Antagonistic action of siderophores from Rhodotorula glutinis upon the postharvest pathogen Penicillium expansum. Int. Biodeterior. Biodegrad. 1999, 43, 167-172. [CrossRef]

74. Hummel, W.; Diekmann, H. Preliminary characterization of ferrichrome synthetase from Aspergillus quadricinctus. Biochim. Biophys. Acta 1981, 657, 313-320. [CrossRef]

75. Yuan, W.M.; Gentil, G.D.; Budde, A.D.; Leong, S.A. Characterization of the Ustilago maydis sid2 gene, encoding a multidomain peptide synthetase in the ferrichrome biosynthetic gene cluster. J. Bacteriol. 2001, 183, 4040-4405. [CrossRef]

76. Wilhite, S.E.; Lumsden, R.D.; Straney, D.C. Peptide synthetase gene in Trichoderma virens. Appl. Environ. Microbiol. 2001, 67, 5055-5062. [CrossRef]

77. Leong, S.A.; Winkelmann, G. Molecular biology of iron transport in fungi. Met. Ions Biol. Syst. 1998, 35, $147-186$.

78. Ahmad, E.; Holmstrom, S.J.M. Siderophores in environmental research: Roles and applications. Microb. Biotechnol. 2014, 7, 196-208. [CrossRef]

79. Sanchez, N.; Brown, E.A.; Olsen, Y.; Vadstein, O.L.; Humberto, E.; Gonzalez, I.; Van Ardelan, M. Effect of Siderophore on Iron Availability in a Diatom and a Dinoflagellate Species: Contrasting Response in Associated Bacteria. Front. Mar. Biol. 2018, 5, 1-18. [CrossRef]

80. Ernst, J.F.; Bennet, R.L.; Rothfield, L.I. Cunstitutive expression if the iron-enterochelin and ferrichrome uptake systems in a mutant strain of Salmonella typhimurium. J. Bacteriol. 1978, 135, 928-934. [CrossRef] [PubMed]

81. Hantke, K. Cloning of the repressor protein gene of iron regulated systems in E. coli K12. Mol. Gen. Genet. 1984, 197, 337-341. [CrossRef]

82. De Lorenzo, V.; Bindereif, A.; Paw, B.H.; Neilands, J.B. Aerobactin biosynthesis and transport genes of plasmid ColV-K30 in Escherichia coli K-12. J. Bacteriol. 1986, 165, 570-578. [CrossRef] [PubMed]

83. Tanui, C.K.; Shyntum, D.Y.; Priem, S.L.; Theron, J.; Moleleki, L.N. Influence of the ferric uptake regulator (Fur) protein on pathogenicity in Pectobacterium Carotovorum subsp. Brasiliense. PLoS ONE 2017, 12, e0177647. [CrossRef]

84. Scazzocchio, C. The fungal GATA factors. Curr. Opin. Microbiol. 2000, 3, 126-131. [CrossRef]

85. Kim, I.H.; Wen, Y.; Son, J.S.; Lee, K.H.; Kim, K.S. The Fur-Iron Complex Modulates Expression of the Quorum-Sensing Master Regulator, SmcR, To Control Expression of Virulence Factors in Vibrio vulnificus. Infect. Innum. 2013, 81, 2888-2898. [CrossRef] [PubMed]

86. An, Z.; Mei, B.; Yuan, W.M.; Leong, S.A. The distal GATA sequences of the sid1 promoter of Ustilago maydis mediate iron repression of siderophore production and interact directly with Urbs1, a GATA family transcription factor. EMBO J. 1997, 16, 1742-1750. [CrossRef]

87. Gauthier, G.M.; Sullivan, T.D.; Gallardo, S.S.; Brandhorst, T.T.; Wymelenberg, V.; Cuomo, C.A.; Suen, G.; Currie, C.R.; Klein, B.S. SREB, a GATA Transcription Factor That Directs Disparate Fates in Blastomyces dermatitidis Including Morphogenesis and Siderophore Biosynthesis. PLoS Pathog. 2010, 6, e1000846. [CrossRef] [PubMed]

88. Voisard, C.; Wang, J.; McEvoy, J.L.; Xu, P.; Leong, S.A. Urbsl, a gene regulating siderophore biosynthesis in Ustilago maydis, encodes a protein similar to the erythroid transcription factor GATA-1. Mol. Cell. Biol. 1993, 13, 7091-7100.

89. Zhou, L.W.; Haas, H.; Marzluf, G.A. Isolation and characterization of a new gene, sre, which encodes a GATAtype regulatory protein that controls iron transport in Neurospora crassa. Mol. Gen. Genet. 1998, 259, 532-540. [CrossRef] 
90. Haas, H.; Angermayr, K.; Zadra, I.; Stoffler, G. Overexpression of nreB, a new GATA factor-encoding gene of Penicillium chrysogenum, leads to repression of the nitrate assimilatory gene cluster. J. Biol. Chem. 1997, 272, 22576-225882. [CrossRef] [PubMed]

91. Haas, H.; Zadra, I.; Stoffler, G.; Angermaryr, K. The Aspergillus nidulans GATA factor SREA is involved in regulation of siderophore biosynthesis and control of iron uptake. J. Biol. Chem. 1999, 274, 4613-4619. [CrossRef] [PubMed]

92. Hoe, K.L.; Won, M.S.; Yoo, O.J.; Yoo, H.S. Molecular cloning of GAF2, a Schizosaccharomyces pombe GATA factor, which has two zinc-finger sequences. Biochem. Mol. Biol. Int. 1996, 39, 127-135. [CrossRef] [PubMed]

93. Pelletier, B.; Trott, A.; Morano, K.A.; Labbe, S. Functional characterization of the iron-regulatory transcription factor Fep1 from Schizosaccharomyces pombe. J. Biol. Chem. 2005, 280, 25146-25161. [CrossRef] [PubMed]

94. Yamaguchi-Iwai, Y.; Dancis, A.; Klausner, R.D. AFT1: A mediator of iron regulated transcriptional control in Saccharomyces cerevisiae. EMBO J. 1995, 14, 1231-1239. [CrossRef]

95. Yamaguchi-Iwai, Y.; Stearman, R.; Dancis, A.; Klausner, R.D. Iron-regulated DNA binding by the AFT1 protein controls the iron regulon in yeast. EMBO J. 1996, 15, 3377-3384. [CrossRef] [PubMed]

96. McRose, D.L.; Baars, O.; Seyedsayamdost, M.R.; Morel, F. Quorum sensing and iron regulate a two-for-one siderophore gene cluster in Vibrio harveyi. Proc. Natl. Acad. Sci. USA 2018, 115, 7581-7586. [CrossRef] [PubMed]

97. Tshikantwa, T.S.; Ullah, M.W.; He, F.; Yanh, G. Current Trends and Potential Applications of Microbial Interactions for Human Welfare. Front. Microbiol. 2018, 9, 1156. [CrossRef]

98. Butler, A. Marine siderophores and microbial iron mobilization. Biometals 2005, 18, 369-374. [CrossRef] [PubMed]

99. Emerson, D. Biogeochemistry and microbiology of microaerobic Fe(II) oxidation. Biochem. Soc. Trans. 2012, 40, 1211-1216. [CrossRef] [PubMed]

100. Cornelissen, C.N.; Sparling, P.F. Neisseria. Iron Transp. Bact. 2004, 2004, 256-272.

101. Butt, A.T.; Thomas, M.S. Iron acquisition mechanisms and their role in the virulence of Burkholderia species. Front. Cell Infect. Microbiol. 2017, 7, 460. [CrossRef] [PubMed]

102. Li, Y.; Wang, Z.K.; Liu, X.; Song, Z.Y.; Li, R.; Shao, C.W.; Yin, Y.P. Siderophore Biosynthesis but Not Reductive Iron Assimilation Is Essential for the Dimorphic Fungus Nomuraea rileyi Conidiation, Dimorphism Transition, Resistance to Oxidative Stress, Pigmented Microsclerotium Formation, and Virulence. Front. Microbiol. 2016, 7, 931. [CrossRef] [PubMed]

103. Matzanke, B.F.; Bill, E.; Trautwein, A.X.; Winkelmann, G. Ferricrocin functions as the main intracellular iron-storage compound in mycelia of Neurospora crassa. Biol. Met. 1988, 1, 18-25. [CrossRef]

104. Eisendle, M.; Oberegger, H.; Zadra, I.; Haas, H. The siderophore system is essential for viability of Aspergillus nidulans: Functional analysis of two genes encoding 1-ornithine N5-monooxygenase (sidA) and a non-ribosomal peptide synthetase (sidC). Mol. Microbiol. 2003, 49, 359-375. [CrossRef]

105. Garcia-Rubio, R.; de Oliveira, H.C.; Rivera, J.; Trevijano-Contador, N. The Fungal Cell Wall: Candida, Cryptococcus, and Aspergillus Species. Front. Microbiol. 2020, 10, 2993. [CrossRef] [PubMed]

106. Orlean, P. The Molecular and Cellular Biology of the Yeast Saccharomyces; Cell Cycle and Cell, Biology; Pringle, J.R., Broach, j.R., Jones, E.W., Eds.; Cold Spring Harbor Laboratory Press: Cold Spring Harbor, NY, USA, 1997; pp. 229-362.

107. Marathe, R.; Phatake, Y.; Sonawane, A. Bioprospecting of Pseudomonas aeruginosa for their potential to produce siderophore: Process optimization and evaluation of its bioactivity. Int. J. Bioassays 2015, 4, 3667-3675.

108. Johnstone, T.; Nolan, E. Beyond iron: Non-classical biological functions of bacterial siderophores. Dalton Trans. 2015, 44, 6320-6339. [CrossRef] [PubMed]

109. Renshaw, J.; Robson, G.; Trinci, A.; Wiebe, M.; Livens, F.; Collison, D.; Taylor, R. Fungal siderophores: Structures, functions and applications. Mycol. Res. 2002, 106, 1123-1142. [CrossRef]

110. Huschka, H.G.; Jalal, M.A.F.; Helm, D.V.D.; Winkelmann, G. Molecular recognition of siderophores in fungi: Role of ironsurrounding $\mathrm{N}$-acyl residues and the peptide backbone during membrane transport in Neurospora crassa. J. Bacteriol. 1986, 167, 1020-1024. [CrossRef] [PubMed]

111. Protchenko, O.; Ferea, T.; Rashford, J.; Tiedeman, J.; Brown, P.O.; Botstein, D.; Philpott, C.C. Three cell wall mannoproteins facilitate the uptake of iron in Saccharomyces cerevisiae. J. Biol. Chem. 2001, 276, 49244-49250. [CrossRef] [PubMed]

112. Van, H.O.; Ward, A.; Kaplan, J. Transition metal transport in yeast. Ann. Rev. Microbiol. 2002, 56, 237-261. [CrossRef] [PubMed]

113. Kosman, D.J. Molecular mechanisms of iron uptake in fungi. Mol. Microbiol. 2003, 47, 1185-1197. [CrossRef]

114. Hassett, R.; Kosman, D.J. Evidence for Cu(II) reduction as a component of copper uptake by Saccharomyces cerevisiae. J. Biol. Chem. 1995, 270, 128-134. [CrossRef] [PubMed]

115. Knight, S.A.B.; Lesuisse, E.; Stearman, R.; Klausner, R.D.; Dancis, A. Reductive iron uptake by Candida albicans: Role of copper, iron and the TUP1 regulator. Microbiology-SGM 2002, 148, 29-40. [CrossRef]

116. Finegold, A.A.; Shatwell, K.P.; Segal, A.W.; Klausner, R.D.; Dancis, A. Intramembrane bis-heme motif for transmembrane electron transport conserved in a yeast iron reductase and the human NADPH oxidase. J. Biol. Chem. 1996, 271, 31021-31024. [CrossRef]

117. Yun, C.W.; Ferea, T.; Rashford, J.; Ardon, O.; Brown, P.O.; Botstein, D.; Kaplan, J.; Philpott, C.C. Desferrioxamine-mediated Iron Uptake in Saccharomyces cerevisiae; evidence for two pathways of iron uptake. J. Biol. Chem. 2000, 275, 10709-10715. [CrossRef]

118. Yun, C.W.; Bauler, M.; Moore, R.E.; Klebba, P.E.; Philpott, C.C. The Role of the FRE Family of Plasma Membrane Reductases in the Uptake of Siderophore-Iron in Saccharomyces cerevisiae. J. Biol. Chem. 2001, 276, 10218-10223. [CrossRef] 
119. Dhungana, S.; Crumbliss, A.L. Coordination chemistry and redox processes in siderophore-mediated iron transport. Geomicrobiol. J. 2005, 22, 87-98. [CrossRef]

120. Askwith, C.; Eide, D.; Van Ho, A.; Bernard, P.S.; Li, L.; Davis Kaplan, S.; Sipe, D.M.; Kaplan, J. The FET3gene of S. cerevisiae encodes a multicopper oxidase required for ferrous iron uptake. Cell 1994, 76, 403-410. [CrossRef]

121. Dancis, A.; Roman, D.G.; Anderson, G.J.; Hinnebusch, A.G.; Klausner, R.D. Ferric reductase of Saccharomyces cerevisiae: Molecular characterization, role in iron uptake, and transcriptional control by iron. Proc. Natl. Acad. Sci. USA 1992, 89, 3869-3873. [CrossRef] [PubMed]

122. De Silva, D.; Davis-Kaplan, S.; Fergestad, J.; Kaplan, J. Purification and characterization of Fet3 protein, a yeast homologue of ceruplasmin. J. Biol. Chem. 1997, 272, 14208-14213. [CrossRef] [PubMed]

123. Hassett, R.F.; Romeo, A.M.; Kosman, D.J. Regulation of high affinity iron uptake in the yeast Saccharomyces cerevisiae. Role Dioxygen Fe J. Biol. Chem. 1998, 273, 7628-7636. [CrossRef]

124. Lin, S.J.; Pufahl, R.A.; Dancis, A.; O'Halloran, T.V.; Culotta, V.C. A role for the Saccharomyces cerevisiae ATX1 gene in copper trafficking and iron transport. J. Biol. Chem. 1997, 272, 9215-9220. [CrossRef] [PubMed]

125. Yuan, D.S.; Stearman, R.; Dancis, A.; Dunn, T.; Beeler, T.; Klausner, R.D. The Menkes/Wilson disease gene homologue in yeast provides copper to a ceruloplasmin-like oxidase required for iron uptake. Proc. Natl. Acad. Sci. USA 1995, 92, 2632-2636. [CrossRef]

126. Dunaief, J.L.; Strober, B.E.; Guha, S.; Khavari, P.A.; Ålin, K.; Luban, J.; Begemann, M.; Crabtree, G.R.; Goff, S.P. The retinoblastoma protein and BRG1 form a complex and cooperate to induce cell cycle arrest. Cell 1994, 79, 119-130. [CrossRef]

127. Felice, M.R.; De Domenico, I.; Li, L.; Ward, D.M.; Bartok, B.; Musci, G.; Kaplan, J. Post-transcriptional regulation of the yeast high affinity iron transport system. J. Biol. Chem. 2005, 280, 22181-22190. [CrossRef] [PubMed]

128. Hsiang, T.; Baillie, D.L. Comparison of the Yeast Proteome to Other Fungal Genomes to Find Core Fungal Genes. J. Mol. Evol. 2005, 60, 475-483. [CrossRef]

129. Day, J.P.; Ackrill, P. The chemistry of desferrioxamine chelation for aluminium overload in renal dialysis patients. Ther. Drug Monit. 1993, 15, 598-601. [CrossRef] [PubMed]

130. Faa, G.; Crisponi, G. Iron chelating agents in clinical practice. Coord. Chem. Rev. 1999, 184, 291-310. [CrossRef]

131. Peterson, C.M.; Garziano, J.H.; Grady, R.W.; Jones, R.L.; Vlassara, H.V.; Canale, V.C.; Miller, D.R.; Cerami, A. Chelation studies with 2,3-dihydroxybenzoic acid in patients with thalassaemia major. Br. J. Haematol. 1976, 33, 477-485. [CrossRef] [PubMed]

132. Kontoghiorghes, G.J. Comparative efficacy and toxicity of desferrioxamine, deferriprone and other iron and aluminium che-lating drugs. Toxicol. Lett. 1995, 80,1-18.

133. Dexter, D.T.; Ward, R.J.; Florence, A.; Jenners, P.; Crichton, R.R. Effects of desferrithiocin and its derivatives on peripheral iron and striatal dopamine and 5-hydroxytryptamine metabolism in ferrocene-loaded rat. Biochem. Pharmacol. 1999, 58, 151-155. [CrossRef]

134. Martell, S.J.D.; Beattie, A.I.; Walters, C.J.; Nayar, T.; Briese, R. Simulating fisheries management strategies in the Strait of Georgia ecosystem using Ecopath and Ecosim. Fish. Cent. Res. Rep. 2002, 10, 16-23.

135. Bergeron, R.J.; Wollenweber, M.; Wiegand, J. An investigation of desferrithiocin metabolism. J. Med. Chem. 1994, 37, $2889-2895$. [CrossRef]

136. Grady, R.W.; Peterson, C.M.; Jones, R.L.; Graziano, J.H.; Bhargava, K.K.; Berdoukas, V.A.; Kokkini, G.; Loukopoulos, D.; Cerami, A. Rhodotorulic acid - investigation of its potential as an iron-chelating drug. J. Pharmacol. Exp. Ther. 1979, $209,342-348$.

137. Stradling, G.N. Decorporation of actinides: A review of recent research. J. Alloys Compd. 1998, 271/273, 11-12. [CrossRef]

138. Weinberg, E.D. The role of iron in protozoan and fungal infectious diseases. J. Eukaryot. Microbiol. 1999, 46, 231-238. [CrossRef]

139. Estrov, Z.; Tawa, A.; Wang, X.H.; Pube, I.D.; Cohen, A.; Gelfand, E.W.; Freedman, M.H. In vitro and in vivo effects of deferoxamine in neonatal acute leukemia. Blood 1987, 69, 757-761. [CrossRef] [PubMed]

140. Vergne, A.F.; Walz, A.J.; Miller, M.J. Iron chelators from mycobacteria and potential therapeutic applications. Nat. Prod. Rep. 2000, 17, 99-116. [CrossRef] [PubMed]

141. Lu, Y.; Miller, M.J. Syntheses and studies of multi warhead siderophore-5-fluorouridine conjugates. Bioorg. Med. Chem. 1999, 7, 3025-3038. [CrossRef]

142. Durbin, P.W.; Kullgren, B.; Xu, J.; Raymon, K.N. New agents for in vivo chelation of uranium (VI): Efficacy and toxicity in mice of multidentate catecholate and hydroxypyridinonate ligands. Health Phys. 1997, 72, 865-879. [CrossRef]

143. Ghosh, A.; Miller, M.J. Synthesis of novel citrate-based siderophores and siderophore-beta-lactam conjugates. Iron transportmediated drug delivery systems. J. Org. Chem. 1993, 58, 7652-7659. [CrossRef]

144. Minnick, A.A.; McKee, J.A.; Dolence, E.K.; Miller, M.J. Iron transport-mediated antibacterial activity and development of resistance to hydroxamate and catechol siderophore-carbacephalosporin conjugates. Antimicrob. Agents Chemother. 1992, 36, 840-850. [CrossRef]

145. Wencewicz, T.A.; Long, T.E.; Möllmann, U.; Miller, M.J. Trihydroxamate siderophore-fluoroquinolone conjugates are selective sideromycin antibiotics that target Staphylococcus aureus. Bioconjugate Chem. 2013, 24, 473-486. [CrossRef] [PubMed]

146. Rivault, F.; Liébert, C.; Burger, A.; Hoegy, F.; Abdallah, M.A.; Schalk, I.J.; Mislin, G.L.A. Synthesis of pyochelin-norfloxacin conjugates. Bioorg. Med. Chem. Lett. 2007, 17, 640-644. [CrossRef]

147. Souto, A.; Montaos, M.A.; Balado, M.; Osorio, C.R.; Rodríguez, J.; Lemos, M.L.; Jiménez, C. Synthesis and antibacterial activity of conjugates between norfloxacin and analogues of the siderophore vanchrobactin. Bioorg. Med. Chem. 2013, 21, 295-302. [CrossRef] 
148. Möllmann, U.; Ghosh, A.; Dolence, E.K.; Dolence, J.A.; Reissbrodt, R. Selective growth promotion and growth inhibition of Gram-negative and Gram-positive bacteria by synthetic siderophore- $\beta$-lactam conjugates. Biometals 1998, 11, 1-12. [CrossRef] [PubMed]

149. Petrik, M.; Pfister, J.; Misslinger, M.; Decristoforo, C.; Haas, H. Siderophore-Based Molecular Imaging of Fungal and Bacterial Infections-Current Status and Future Perspectives. J. Fungi 2020, 6, 73. [CrossRef]

150. Bergeron, R.J.; Bharti, N.; Singh, S.; Mcmanis, J.S.; Wiegand, J.; Green, L.G. Vibriobactin antibodies: A vaccine strategy. J. Med. Chem. 2009, 52, 3801-3813. [CrossRef]

151. Mike, L.; Smith, S.; Sumner, C.; Mobley, H. LB-S \& T-35 siderophore vaccine conjugates protect against uropathogenic Escherichia coli in a murine model of urinary tract infection. J. Urol. 2016, 195, e351.

152. Mike, L.A.; Smith, S.N.; Sumner, C.A.; Eaton, K.A.; Mobley, H.L.T. Siderophore vaccine conjugates protect against uropathogenic Escherichia coli urinary tract infection. Proc. Natl. Acad. Sci. USA 2016, 113, 13468-13473. [CrossRef]

153. Brumbaugh, A.R.; Smith, S.N.; Mobley, H.L. Immunization with the yersiniabactin receptor, FyuA, protects against pyelonephritis in a murine model of urinary tract infection. Infect. Immun. 2013, 81, 3309-3316. [CrossRef] [PubMed]

154. Fox, J.T.; Thomson, D.U.; Drouillard, J.S.; Thornton, A.B.; Nagaraja, T.G. Efficacy of Escherichia coli O157: H7 siderophore receptor/porin proteins-based vaccine in feedlot cattle naturally shedding E. coli O157. Foodborne Pathog. Dis. 2009, 6, 893-899. [CrossRef] [PubMed]

155. Mariotti, P.; Malito, E.; Biancucci, M.; Surdo, P.L.; Bottomley, M.J. Structural and functional characterization of the Staphylococcus aureus virulence factor and vaccine candidate FhuD2. Biochem. J. 2013, 449, 683-693. [CrossRef] [PubMed]

156. Sanguinetti, M.; Posteraro, B.; Beigelman-Aubry, C.; Lamoth, F.; Dunet, V.; Slavin, M.; Richardson, M.D. Diagnosis and treatment of invasive fungal infections: Looking ahead. J. Antimicrob. Chemother. 2019, 74, ii27-ii37. [CrossRef]

157. Petrik, M.; Haas, H.; Dobrozemsky, G.; Lass-Florl, C.; Helbok, A.; Blatzer, M.; Dietrich, H.; Decristoforo, C. ${ }^{68}$ Ga-siderophores for PET imaging of invasive pulmonary aspergillosis: Proof of principle. J. Nucl. Med. 2010, 51, 639-645. [CrossRef]

158. Petrik, M.; Haas, H.; Schrettl, M.; Helbok, A.; Blatzer, M.; Decristoforo, C. In vitro and in vivo evaluation of selected ${ }^{68}$ Gasiderophores for infection imaging. Nucl. Med. Biol. 2012, 39, 361-369. [CrossRef] [PubMed]

159. Petrik, M.; Haas, H.; Laverman, P.; Schrettl, M.; Franssen, G.M.; Blatzer, M.; Decristoforo, C. ${ }^{68}$ Ga-triacetylfusarinine C and ${ }^{68}$ Ga-ferrioxamine e for aspergillus infection imaging: Uptake specificity in various microorganisms. Mol. Imaging Biol. 2014, 16, 102-108. [CrossRef]

160. Kaeopookum, P.; Summer, D.; Pfister, J.; Orasch, T.; Lechner, B.E.; Petrik, M.; Novy, Z.; Matuszczak, B.; Rangger, C.; Haas, H.; et al. Modifying the siderophore triacetylfusarinine C for molecular imaging of fungal infection. Mol. Imaging Biol. 2019, 21, 1097-1106. [CrossRef]

161. Pfister, J.; Summer, D.; Petrik, M.; Khoylou, M.; Lichius, A.; Kaeopookum, P.; Kochinke, L.; Orasch, T.; Haas, H.; Decristoforo, C. Hybrid imaging of aspergillus fumigatus pulmonary infection with fluorescent, ${ }^{68} \mathrm{Ga}$-labelled siderophores. Biomolecules $\mathbf{2 0 2 0}$ 10, 168. [CrossRef]

162. Lu, Y.; Wang, H.Y.; Wang, Z.Z.; Cong, Y.; Zhang, P.; Liu, G.L.; Liu, C.G.; Chi, Z.M.; Chi, Z. Metabolic rewiring improves the production of the fungal active targeting molecule Fusarinine C. ACS Synth. Biol. 2019, 8, 1755-1765. [CrossRef]

163. Skriba, A.; Pluhacek, T.; Palyzova, A.; Novy, Z.; Lemr, K.; Hajduch, M.; Petrik, M.; Havlicek, V. Early and non-invasive diagnosis of aspergillosis revealed by infection kinetics monitored in a rat model. Front. Microbiol. 2018, 9, 2356. [CrossRef]

164. Hoenigl, M.; Orasch, T.; Faserl, K.; Prattes, J.; Loeffler, J.; Springer, J.; Gsaller, F.; Reischies, F.; Duettmann, W.; Raggam, R.B.; et al. Triacetylfusarinine C: A urine biomarker for diagnosis of invasive aspergillosis. J. Infect. 2019, 78, 150-157. [CrossRef]

165. Wasi, S.; Tabrez, S.; Ahmad, M. Toxicological effects of major environmental pollutants: An overview. Environ. Monit. Assess. 2013, 185, 2585-2593. [CrossRef]

166. Schalk, I.J.; Hannauer, M.; Braud, A. New roles for bacterial siderophores in metal transport and tolerance. Environ. Microbiol. 2011, 13, 2844-2854. [CrossRef]

167. Hernlem, B.J.; Vane, L.M.; Sayles, G.D. The application of siderophores for metal recovery and waste remediation: Examination of correlations for prediction of metal affinities. Water Res. 1999, 33, 951-960. [CrossRef]

168. Barton, L.E.; Quicksall, A.N.; Maurice, P.A. Siderophore-mediated dissolution of hematite $\left(\alpha-\mathrm{Fe}_{2} \mathrm{O}_{3}\right)$ : Effects of nanoparticle size. Geomicrobiol. J. 2012, 29, 314-322. [CrossRef]

169. Sinha, S.; Mukherjee, S.K. Cadmium-induced siderophore production by a high cd-resistant bacterial strain relieved cd toxicity in plants through root colonization. Curr. Microbiol. 2008, 56, 55-60. [CrossRef]

170. Dimkpa, C.O.; Merten, D.; Svato, A.; Buchel, G.; Kothe, E. Metal-induced oxidative stress impacting plant growth in contaminated soil is alleviated by microbial siderophores. Soil Biol. Biochem. 2009, 41, 154-162. [CrossRef]

171. Compant, D.; Nowak, C.; Barka, E.A. Use of plant growth-promoting bacteria for biocontrol of plant diseases: Principles, mechanisms of action, and future prospects. Appl. Environ. Microbiol. 2005, 71, 4951-4959. [CrossRef]

172. Kayser, A.; Wenger, K.; Keller, A.; Attinger, W.; Felix, H.R.; Gupta, S.K.; Schulin, R. Enhancement of phytoextraction of Zn, Cd, and $\mathrm{Cu}$ from calcareous soil: The use of NTA and sulfur amendments. Environ. Sci. Technol. 2000, 34, 1778-1783. [CrossRef]

173. Braud, A.; Jézéquel, K.; Bazot, S.; LEb Eau, T. Enhanced phytoextraction of an agricultural $\mathrm{Cr}$ and Pb contaminated soil by bioaugmentation with siderophore-producing bacteria. Chemosphere 2008, 74, 280-286. [CrossRef]

174. Dahlheimer, S.R.; Neal, C.R.; Fein, J.B. Potential mobilization of platinum-group elements by siderophores in surface environments. Environ. Sci. Technol. 2007, 41, 870-875. [CrossRef] 
175. Hong, J.W.; Park, J.Y.; Gadd, G.M. Pyrene degradation and copper and zinc uptake by Fusarium solani and Hypocrea lixii isolated from petrol station soil. J. Appl. Microbiol. 2010, 108, 2030-2040. [PubMed]

176. Duckworth, O.W.; Sposito, G. Siderophore-Manganese(III) Interactions II. Manganite Dissolution Promoted by Desferrioxamine B. Environ. Sci. Technol. 2005, 39, 6045-6051. [CrossRef]

177. Hesse, E.; O’Brien, S.; Tromas, N.; O'Brien, S.; Tromas, N.; Bayer, F.; Luján, A.M.; van Veen, E.M.; Hodgson, D.J.; Buckling, A.; et al. Ecological selection of siderophore-producing microbial taxa in response to heavy metal contamination. Ecol. Lett. 2018, 21, 117-127. [CrossRef]

178. Ledin, M.; Pedersen, K. The environmental impact of mine wastes-roles of microorganisms and their significance in treatment of mine wastes. Earth Sci. Rev. 1996, 41, 67-108. [CrossRef]

179. Gray, S.N. Fungi as potential bioremediation agents in soil contaminated with heavy or radioactive metals. Biochem. Soc. Trans. 1998, 26, 666-670. [CrossRef]

180. Gopalan, A.S.; Huber, V.J.; Zincircioglu, O.; Smith, P.H. Novel tetrahydroxamate chelators for actinide complexation: Synthesis and binding studies. J. Chem. Soc. Chem. Commun. 1992, 17, 1266-1268. [CrossRef]

181. Brainard, J.R.; Strietelmeier, B.A.; Smith, P.H.; Langsten-Unkefer, P.F.; Barr, M.E.; Ryan, R.R. Actinide binding and solubilization by microbial siderophores. Radiochim. Acta 1992, 58/59, 357-363. [CrossRef]

182. Neubauer, U.; Nowak, B.; Furrer, G.; Schulin, R. Heavy metal sorption on clay minerals affected by the siderophore desferrioxamine B. Environ. Sci. Technol. 2000, 34, 2749-2755. [CrossRef]

183. Kraemer, D.; Tepe, N.; Pourret, O.; Bau, M. Negative cerium anomalies in manganese (hydr)oxide precipitates due to cerium oxidation in the presence of dissolved siderophores. Geochim. Cosmochim. Acta 2016, 196, 197-208. [CrossRef]

184. Crowley, D.E.; Reid, C.P.; Szaniszlo, P.J. Utilization of microbial siderophores in iron acquisition by oat. Plant Physiol. 1988, 87 , 680-685. [CrossRef]

185. Ruggiero, C.E.; Neu, M.P.; Vanderberg, L.A. Plutonium and uranium interactions with siderophores of aerobic soil microbes. J. Inorg. Biochem. 1999, 74, 282.

186. Crowley, D.A. Microbial siderophores in the plant rhizosphere. In Iron Nutrition in Plants and Rhizospheric Microorganisms; Barton, L.L., Abadía, J., Eds.; Springer: Berlin/Heidelberg, Germany, 2006; Volume 614, pp. 169-189.

187. Mengel, K. Iron availability in plant tissues-Iron chlorosis on calcareous soils. In Iron Nutrition in Soils and Plants; Abadia, J., Ed.; Kluwer: Dordrecht, The Netherlands, 1995; pp. 389-397.

188. Kosegarten, H.U.; Hoffmann, B.; Mengel, K. Apoplastic $\mathrm{pH}$ and Fe3+ reduction in intact sunflower leaves. Plant Physiol. 1999, 121, 1069-1079. [CrossRef]

189. Masalha, J.; Kosegarten, H.; Elmacio, M.K. The central role of microbial activity for iron acquisition in maize and sunflower. Biol. Fertil. Soils 2000, 30, 433-439. [CrossRef]

190. Schenk, P.M.; Carvalhais, L.C.; Kazan, K. Unraveling plant-microbe interactions: Can multi-species transcriptomics help? Trends Biotechnol. 2012, 30, 177-184. [CrossRef]

191. Caris, C.; Hordt, W.; Hawkins, H.J.; Römheld, V.; George, E. Studies of iron transport by arbuscular mycorrhizal hyphae from soil to peanut and sorghum plants. Mycorrhiza 1998, 8, 35-39. [CrossRef]

192. Sagar, A.; Rathore, P.; Ramteke, P.W.; Ramakrishna, W.; Reddy, M.S.; Pecoraro, L. Plant Growth Promoting Rhizobacteria, Arbuscular Mycorrhizal Fungi and Their Synergistic Interactions to Counteract the Negative Effects of Saline Soil on Agriculture: Key Macromolecules and Mechanisms. Microorganisms 2021, 9, 1491. [CrossRef]

193. Yadav, S.; Kaushik, R.; Saxena, A.K.; Arora, D.K. Diversity and phylogeny of plant growth-promoting bacilli from moderately acidic soil. J. Basic Microbiol. 2011, 51, 98-106. [CrossRef]

194. Shah, D.; Khan, M.S.; Aziz, S.; Ali, H.; Pecoraro, L. Molecular and Biochemical Characterization, Antimicrobial Activity, Stress Tolerance, and Plant Growth-Promoting Effect of Endophytic Bacteria Isolated from Wheat Varieties. Microorganisms $2022,10,21$. [CrossRef]

195. Schippers, B.; Lugtenberg, B.; Weisbeek, P.J. Plant growth control by fluorescent pseudomonads. In Innovative Approaches to Plant Disease Control; Chet, J., Ed.; Wiley: New York, NY, USA, 1987; pp. 19-36.

196. Gamalero, E.; Glick, B.R. Mechanisms used by plant growth-promoting bacteria. In Bacteria in Agrobiology: Plant Nutrient Management; Maheshwari, M.K., Ed.; Springer: Berlin/Heidelberg, Germany, 2011; pp. 17-46.

197. Bergeron, R.J.; Braylan, R.; Goldey, S.; Ingeno, M. Effects of the Vibrio cholerae siderophore vibriobactin on the growth characteristics of L1210 cells. Biochem. Biophys. Res. Commun. 1986, 136, 273-280. [CrossRef]

198. Hider, R.C.; Kong, X. Chemistry and biology of siderophores. Nat. Prod. Rep. 2010, 27, 637-657. [CrossRef] [PubMed]

199. Sazinas, P.; Hansen, M.L.; Aune, M.I.; Fischer, M.H.; Jelsbak, L. A rare thioquinolobactin siderophore present in a bioactive Pseudomonas sp. DTU12.1. Genome Biol. Evol. 2019, 11, 3529-3533. [CrossRef]

200. Samsonov, S.A.; Zsila, F.; Maszota-Zieleniak, M. Acute phase $\alpha 1$-acid glycoprotein as a siderophore-capturing component of the human plasma: A molecular modeling study. J. Mol. Graph. Model. 2021, 105, 107861. [CrossRef]

201. Xie, F.; Dai, S.; Zhao, Y.; Huang, P.; Yu, S.; Ren, B.; Wang, Q.; Ji, Z.; Alterovitz, G.; Zhang, Q.; et al. Generation of fluorinated amychelin siderophores against Pseudomonas aeruginosa infections by a combination of genome mining and mutasynthesis. Cell Chem. Biol. 2020, 27, 1532-1543. [CrossRef]

202. Swayambhu, G.; Moscatello, N.; Atilla-Gokcumen, G.E.; Pfeifer, B.A. Flux balance analysis for media optimization and genetic targets to improve heterologous siderophore production. Iscience 2020, 23, 101016. [CrossRef] [PubMed] 
203. Kraemer, S.M. Iron oxide dissolution and solubility in the presence of siderophores. Aquat. Sci. 2004, 66, 3-18. [CrossRef]

204. Shirvani, M.; Nourbakhsh, F. Desferrioxamine-B adsorption to and iron dissolution from palygorskite and sepiolite. Appl. Clay Sci. 2010, 48, 393-397. [CrossRef]

205. Holmén, B.A.; Casey, W.H. Hydroxamate ligands, surface chemistry, and the mechanism of ligand-promoted dissolution of goethite $[\alpha-\mathrm{FeOOH}(\mathrm{s})]$. Geochim. Cosmochim. Acta 1996, 60, 4403-4416. [CrossRef]

206. Kalinowski, B.; Liermann, L.J.; Brantley, S.L.; Barnes, A.; Pantano, C.G. X-ray photoelectron evidence for bacteria-enhanced dissolution of hornblende. Geochim. Cosmochim. Acta 2000, 64, 1331-1343. [CrossRef]

207. Matzanke, B.F. Structures, coordination chemistry and functions of microbial iron chelates. In CRC Handbook of Microbial Iron Chelates; CRC Press: Boca Raton, FL, USA, 2017; pp. 15-64.

208. Perrin, D. Stability Constants: Part B; IUPAC: Pergamon, Turkey, 1979.

209. Reichard, P.; Kretzschmar, R.; Kraemer, S.M. Dissolution mechanisms of goethite in the presence of siderophores and organic acids. Geochim. Cosmochim. Acta 2007, 71, 5635-5650. [CrossRef]

210. Watteau, F.; Berthelin, J. Microbial dissolution of iron and aluminium from soil minerals: Efficiency and specificity of hydroxamate siderophores compared to aliphatic acids. Eur. J. Soil Biol. 1994, 30, 1-9.

211. Sokolova, T.; Tolpeshta, I.; Topunova, I. Biotite weathering in podzolic soil under conditions of a model field experiment. Eurasian Soil Sci. 2010, 43, 1150-1158. [CrossRef]

212. Hiradate, S.; Inoue, K. Dissolution of iron from iron (hydr) oxides by mugineic acid. Soil Sci. Plant. Nutr. 1998, 44, 305-313. [CrossRef]

213. Reichard, P.; Kraemer, S.M.; Frazier, S.W.; Kretzschmar, R. Goethite dissolution in the presence of phytosiderophores: Rates, mechanisms, and the synergistic effect of oxalate. Plant Soil 2005, 276, 115-132. [CrossRef]

214. Gómez-Galera, S.; Sudhakar, D.; Pelacho, A.M.; Capell, T.; Christou, P. Constitutive expression of a barley Fe phytosiderophore transporter increases alkaline soil tolerance and results in iron partitioning between vegetative and storage tissues under stress. Plant Physiol. Biochem. 2012, 53, 46-53. [CrossRef]

215. Gledhill, M.; Buck, K.N. The organic complexation of iron in the marine environment: A review. Front. Microbiol. 2012, 3, 69 [CrossRef]

216. Boyd, P.W.; Jickells, T.; Law, C.S.; Blain, S.; Boyle, E.A.; Buesseler, K.O.; Coale, K.H.; Cullen, J.J.; de Baar, H.J.W.; Follows, M.; et al. Mesoscale iron enrichment experiments 1993-2005: Synthesis and future directions. Science 2007, 315, 612-617. [CrossRef]

217. Cordero, O.X.; Ventouras, L.A.; DeLong, E.F.; Polz, M.F. Public good dynamics drive evolution of iron acquisition strategies in natural bacterioplankton populations. Proc. Natl. Acad. Sci. USA 2012, 109, 20059-20064. [CrossRef]

218. Martinez, J.S.; Butler, A. Marine amphiphilic siderophores: Marinobactin structure, uptake, and microbial partitioning. J. Inorg. Biochem. 2007, 101, 1692-1698. [CrossRef]

219. Barbeau, K.; Rue, E.L.; Bruland, K.W.; Butler, A. Photochemical cycling of iron in the surface ocean mediated by microbial iron (III)-binding ligands. Nature 2001, 413, 409-413. [CrossRef]

220. Hunter, K.A.; Boyd, P.W. Iron-binding ligands and their role in the ocean biogeochemistry of iron. Environ. Chem. 2007, 4, 221-232. [CrossRef]

221. Mawji, E.; Gledhill, M.; Milton, J.A.; Tarran, G.A.; Ussher, S.; Thompson, A.; Wolff, G.A.; Worsfold, P.J.; Achterberg, E.P. Hydroxamate siderophores: Occurrence and importance in the Atlantic Ocean. Environ. Sci. Technol. 2008, 42, 8675-8680. [CrossRef]

222. Amin, S.A.; Amin, S.A.; Green, D.H.; Waheeb, D.A.; Gärdes, A.; Carrano, C.J. Iron transport in the genus Marinobacter. Biometals 2012, 25, 135-147. [CrossRef]

223. Asemoloye, M.D.; Marchisio, M.A.; Gupta, V.K.; Pecoraro, L. Genome-based engineering of ligninolytic enzymes in fungi. Microb. Cell Factories 2021, 20, 20. [CrossRef] 